University of Michigan Law School

University of Michigan Law School Scholarship Repository

Articles

Faculty Scholarship

1995

\title{
Prior Statements of a Witness: A Nettlesome Corner of the Hearsay Thicket
}

Richard D. Friedman

University of Michigan Law School, rdfrdman@umich.edu

Available at: https://repository.law.umich.edu/articles/556

Follow this and additional works at: https://repository.law.umich.edu/articles

Part of the Constitutional Law Commons, Criminal Procedure Commons, Evidence Commons, and the Supreme Court of the United States Commons

\section{Recommended Citation}

Friedman, Richard D. "Prior Statements of a Witness: A Nettlesome Corner of the Hearsay Thicket." Sup. Ct. Rev. 1995 (1995): 277-321.

This Article is brought to you for free and open access by the Faculty Scholarship at University of Michigan Law School Scholarship Repository. It has been accepted for inclusion in Articles by an authorized administrator of University of Michigan Law School Scholarship Repository. For more information, please contact mlaw.repository@umich.edu. 


\section{PRIOR STATEMENTS OF A WITNESS:}

\section{A NETTLESOME CORNER OF THE}

HEARSAY THICKET

In Tome $v$ United States, ${ }^{1}$ for the fifth time in eight years, the Supreme Court decided a case presenting the problem of how a child's allegations of sexual abuse should be presented in court. ${ }^{2}$ Often the child who charges that an adult abused her is unable to testify at trial, or at least unable to testify effectively under standard procedures. These cases therefore raise intriguing and difficult questions related to the rule against hearsay and to an accused's right under the Sixth Amendment to confront the witnesses against him.

One would hardly guess that, however, from the rather arid debate in Tome, which focused on a seemingly technical question concerning the interpretation of a provision in the hearsay portion of the Federal Rules of Evidence. In this article, I will examine both that question and some of the broader issues surrounding it. I will use Tome as a vehicle to explore what I believe is the impoverished state of the law concerning the admissibility of prior statements of a witness. This state, I will argue, is attributable in part to the Court's longstanding unwillingness to recognize that a party

Richard D. Friedman is Professor of Law, University of Michigan Law School.

AUthoR's Note: Many thanks to Roger Park for his comments-characteristically perceptive and constructive-on an early draft, and to Mike Thomas for high-quality, high-speed research assistance.

1115 S Ct 696 (1995).

${ }^{2}$ See also Coy v Iowa, 487 US 1012 (1987); Idabo v Wright, 497 US 805 (1990); Maryland v Craig, 497 US 836 (1990); White v Illinois, 502 US 346 (1992).

(c) 1996 by the University of Chicago. All rights reserved.

0-226-36312-0/96/1995-0002\$02.00 
may be substantially hindered in attempting to examine a witness with respect to a prior statement the truth of which the witness no longer affirms. A complete solution to the problem, however, would require a dramatic restructuring of the law of hearsay and confrontation, a prospect that $I$ will touch on only briefly in the conclusion to this article.

\section{The Tome Case: Facts and Opinions}

As in other cases of alleged child sexual abuse, the transcript in Tome makes heartbreaking reading; one way or the other, something horrible has happened.

Matthew and Beverly Tome divorced in September 1988. They had a daughter, then approximately three years and three months old, decorously referred to by the Court as A.T. The parents were awarded joint custody, with Matthew having primary physical custody. During most of the time of concern, he lived on the Navajo Indian Reservation in New Mexico and Beverly hived in Colorado. In August 1990, Beverly, remarried and surnamed Padilla, presented Colorado authorities with allegations that Tome had sexually molested A.T. Tome was charged with sexual abuse of a child in violation of several federal statutes, the superseding indictunent specifying four separate types of improper contact. ${ }^{3}$ The conduct allegedly commenced in about June 1989 , when A.T. turned four. ${ }^{4}$

Tome's trial, in the U.S. District Court for the District of New Mexico, did not begin until February 1992. A.T.-by then approximately six years, eight months old-was the Government's first witness. After she was questioned extensively about her ability to distinguish truth froin a lie, the court allowed her to testify. ${ }^{5} \mathrm{Her}$ testimony on direct examination consisted largely of one- and twoword answers to leading questions, assisted by the use of dolls.

\footnotetext{
${ }^{3}$ They were contact between the penis and the vulva; contact between the mouth and the penis; contact between the mouth and the vulva; improper penetration of the genital opening by hand and finger. Transcript (T) 760-61. See 18 USC $\$ 2246(2)$, formerly $\$ 2245(2)$, defining "sexual act" to include these types of conduct. The conduct alleged was in violation of 18 USC $\$ 1153$, naking a federal offense of certain crimes committed by an Indian "within Indian country," and of 18 USC $\$ 2241$ (c), which criminalizes knowing engagement in a "sexual act" with a child under twelve "in the special maritine and territorial jurisdiction of the United States or in a Federal prison."

${ }^{4}$ Joint Appendix (JA) 2.

"Transcript (T) 69-80.
} 
A.T. testified, in effect, that on one occasion Tome removed their clothes, got on top of her, and put his "private place" where she went "potty" and in her mouth. ${ }^{6}$ After this happened, she said, she went to the bathroom and wiped blood off herself.? Extracting her testimony was a slow process, apparently painful all around; the prosecutor explained, outside the hearing of the jury, that A.T. was "very frightened" of Matthew Tome.

The defense cross-examined A.T. for a total of about an hour and a quarter," first on a Monday afternoon and then again on the Wednesday morning. Much of the examination concerned various

Q: Did daddy take your clothes off, yes or no?

A: Yes.

Q: Okay. Did daddy take his clothes off?

A: Yes.

Q: What did you do with your legs? What did you do?

A: I crossed it.

Q: ... Did daddy do anything?

A: Yes.

Q: And what did daddy do? Go ahead.

A: He got on top of me.

Q: ... Did he do something?

A: Yes.

Q: Was it good something or had something?

A: Bad.

Q: It was bad. Did it hurt or did it feel good?

A: Hurt.

Q: ... Did he put his private place any place on you?

A: Yes.

Q: Where did daddy place his private place, just point, point to me. Point to where you are looking right now ...

Q: What do you call this place? What is that place on you? Do you have a name for that?

A: No.

Q: You don't call it anything? Do you go potty there?

A: Yes.

Q: Okay. And Andrea, where did your daddy place his private thing, anywhere else? And point to me if he did, where. Point to my body wherever he put it. Where? Is that my mouth you are pointing at? Say yes or no.

A: Yes.

Q: All right. Did he put his private thing in your mouth? A: Yes.

T 88-89, 90, 92-93, quoted in part in Petitioner's Brief.

7 T 93-94.

${ }^{8} \mathrm{~T} 91$.

${ }^{9} \mathrm{~T} 166$. 
background issues, such as reasons why A.T. might prefer to live with her mother in Colorado rather than with her father in New Mexico. This line of questioning was clearly intended to support a contention that A.T. had fabricated the allegation of abuse, perhaps at the instigation of her mother, in order to secure a change in her custody arrangement.

In the first session, A.T. gave immediate answers, some in relatively detailed sentences. When A.T. resumed testifying on Wednesday, however, matters were far more strained. Sometimes she answered only after a long interval, estimated by the trial judge to run as much as 45 or 50 seconds, and in the end she provided no audible or discernible responses even to some very simple questions. ${ }^{10}$ During a recess, the judge noted for the record that

the witness seemed to be losing concentration. She would look up to the ceiling, would look to the back of the courtroom, she would look over my head, would not in instances face counsel who is inquiring of her.

She twisted and turned, stretched a little bit sometimes. At other times she would put her hand to her mouth and clasp her lips with her hand. We have a very difficult situation here. "

After A.T. completed her testimony, the Government was allowed to present testimony of several prior statements by A.T. concerning the alleged abuse. It was the admissibility of these statements that created the issue that the Supreme Court chose to review, so it is worth examining them in detail.

Lisa Rocha, a friend of Padilla, testified to a conversation that occurred when she was baby-sitting A.T. on August 22, 1990more than a year after the alleged molestation. At this time, A.T. was concluding a summer in her mother's custody; Padilla was continuing to seek primary custody, but she evidently expected to return A.T. to Tome, ${ }^{12}$ and the next day she was to bring A.T. to New Mexico for a hearing that had been scheduled for August $24 .{ }^{13}$ Rocha testified that A.T. said spontaneously, "Please don't

\footnotetext{
${ }^{10} \mathrm{~T} 125-62$. In a few cases, the difficulty may have been attributable to defense counsel's failure to phrase the question in a way the girl was likely to understand, see T 141, 145, but, as the court indicated, this was not the principal problem. T 147.

" $\mathrm{T} 147-48,3 \mathrm{~F} 3 \mathrm{~d}$ at $348 \mathrm{n} 4$.

${ }_{12} \mathrm{~T} 230$.

${ }^{13} \mathrm{~T}$ 393, 401-04. In fact, the hearing had been rescheduled for August 22, $\mathrm{T}$ 533, so Padilla missed it. T 537-38.
} 
let my mom take [me] back to my father." When Rocha asked her why, the girl responded, "Because I don't want to go back." Pressed further, A.T. said, "Because my father gets drunk and he thinks I'm his wife." 14

According to Rocha, she told Padilla about this conversation only after Padilla returned from New Mexico, still with A.T., ${ }^{15}$ on August 26. After Padilla's unsuccessful effort the next day to get more information from A.T., Rocha questioned A.T. agam. ${ }^{16}$ This time, according to Rocha, A.T. told her that her father "does nasties" to her, and elaborated by saying that (apparently on one occasion) he dragged her through the house by her arms, took her clothes off, forced her legs open, and lay on top of her, which gave her a sharp pain near her stomach. When she cried for her mother, her father told her, "Your mother's a bitch." Furthermore, A.T. related that when she wiped herself the tissue was bloody. ${ }^{17}$

After this conversation, Padilla reported the allegation to the police. ${ }^{18}$ Kae Ecklebarger, a Child Protection Service caseworker assigned to the case, testified that on August 29, 1990, Padilla and Roclia informed lier of the allegation and that she then interviewed A.T. ${ }^{19}$ Ecklebarger asked A.T. if she knew why she was there, and A.T. said it was because of what "Matthew" liad done to lier. A.T. said that she could remember one time particularly clearly. Her father liad told her to remove her clothes, and when she refused he took off her panties, put her on the floor, and "put his balls" in her. Using anatomically correct dolls, A.T. simulated intercourse, and also told Ecklebarger that Tome had kissed her all over her body, including the vaginal area. Ecklebarger also testified that A.T. told her that her father asked her to touch his penis and that she refused. A.T. told once more about wiping herself with a tissue and finding blood, and added that she had slown it to her

${ }^{14}$ JA 11-12, T 218-19.

${ }^{15}$ Apparently on the advice of counsel Padilla returned to Colorado after she missed the hearing, $T$ 404, 447; eventually, after the charges of abuse were made, she was awarded physical custody. T 541-43, 640 .

${ }^{16} \mathrm{~T}$ 220-22. Padilla was histening from an adjoining room and was able to confirm Rocha's testimony only in small part. T 239, 408, JA 20.

${ }^{17}$ JA 12, T 222-23.

${ }^{18}$ Rocba suggested to Padilla that if Padilla made a report to the police she would not have to return A.T. T 450, 451 .

${ }^{19} \mathrm{~T} 340$. 
grandmother and aunt, Tome's mother and sister. ${ }^{20}$ A.T. said that he had engaged in this conduct "every single day" for a time before stopping. ${ }^{21}$

Ecklebarger referred the case to Karen Kuper, a pediatrician. ${ }^{22}$ Dr. Kuper testified that she interviewed A.T. with Padilla present and that when she asked whether anyone had ever touched her in a way that hurt or was scary A.T. answered, "Just iny dad." With the help of anatomical dolls, A.T. said that Toine had touched her vaginal area and put his fingers and his "thing" inside her there. ${ }^{23}$

Another pediatrician, Laura Reich, testified that she examined A.T. on September 21, 1990, for a rash that was apparently unrelated to sexual abuse. During the examination, she asked A.T. if anybody had touched her in her vaginal area and A.T. responded that her father had put his "thing" in her. ${ }^{24} \mathrm{~A}$ third pediatrician, Jean Spiegel, who was an expert in child sexual abuse, examined A.T. on September 3, 1991, about two years after the alleged abuse. Dr. Spiegel testified that A.T. told her, in response to direct questions, that Tome had touched her breasts, her "front privates," and "her bottom where her poop comes out."25

The pediatricians each testified to physical evidence suggesting sexual abuse; Reich spoke most strongly, concluding that A.T. "had definitely had penile penetration in her vaginal area."26 Tome testified in his own defense, denying that he had abused his daughter. ${ }^{27}$ His mother and sister also testified for him, denying that A.T. had ever shown them a bloody tissue, ${ }^{28}$ and several witnesses testified as to his good character. ${ }^{29} \mathrm{He}$ was not permitted to introduce evidence that he had passed a polygraph test denying that he had abused A.T. ${ }^{30}$ The jury returned a verdict of guilty, with an-

\footnotetext{
${ }^{20} \mathrm{JA} 16-19, \mathrm{~T} 317-20$.

${ }^{21} \mathrm{JA} 19, \mathrm{~T} 326$.

$22 \mathrm{~T} 341$.

${ }^{23} \mathrm{JA} 15$, T 255-56.

${ }^{24}$ JA 16, T 290, 292, 298.

${ }^{25}$ JA 20, T 509.

${ }^{28} \mathrm{~T}$ 294. See also T 259-62 (Kuper), 472-73 (Spiegel).

${ }^{27} \mathrm{~T} 642$.

${ }^{28} \mathrm{~T} 607$ (sister), 620, 622 (mother).

${ }^{29} \mathrm{~T} \mathrm{655,660-61,665,671.}$

${ }^{30}$ Record on Appeal, $10 \mathrm{Cir}$, vol 1, at 5-17.
} 
swers to special interrogatories finding that he committed the four types of illicit acts charged, ${ }^{31}$ and the court imposed a sentence of 12 years' imprisonment.

The U.S. Court of Appeals for the Tenth Circuit affirmed the judgment of conviction. The principal issue was the admissibility of A.T.'s out-of-court statements. The Court of Appeals held that all of the statements were admissible under Federal Rules of Evidence $801(\mathrm{~d})(1)(B),{ }^{32}$ which provides:

(d) Statements wbich are not bearsay.-A statement is not hearsay if-

(1) Prior statement by witness.-The declarant testifies at the trial or hearing and is subject to cross-examination concerning the statement, and the statement is . . (B) consistent with the declarant's testimony and is offered to rebut an express or imphed charge against the declarant of recent fabrication or improper influence or motive ....

The court held that A.T. had been adequately subjected to cross-examination (for purposes of both the evidentiary rule and the confrontation clause), notwithstanding her unresponsiveness to some questions, and that Tome had made at least an implicit charge that slie fabricated her testimony out of a preference to live with her mother. Toine argued, lowever, that the Rule could apply ouly to statements inade before the alleged motive to fabricate arose; in this case, he contended, A.T. had made the statements after the motive, lier desire to live with her mother, liad arisen.

Several Courts of Appeals liad indeed held that the Rule incorporates a "premotive" requirement. ${ }^{33}$ But in Tome the Tenth Circuit aligned itself with those Courts of Appeals that had refused to recognize the requirement. ${ }^{34}$ It conceded "that prior consistent statements made after a strong motive to lie has arisen may evi-

\footnotetext{
${ }^{31}$ These are listed in note 3.

${ }^{32}$ This was the principal basis on which the trial court had held the prior statements admissible, though it also held soine of them admissible on alternative grounds, such as the hearsay exception for statements inade for purposes of medical diagnosis or treatment, Rule 803(4).

${ }^{33}$ See, for exaunple, United States $v$ Henderson, 717 F2d 135, 138 (4th Cir 1983); United States v Borman, $798 \mathrm{~F} 2 \mathrm{~d}$ 333, 338 (8th Cir 1986). The decisions adopting this view had, at least for the inost part, done so quite casually. See note 108.

${ }^{34}$ See, for example, United States v Montague, 958 F2d 1094, 1096-99 (DC Cir 1992); United States v Pendas-Martinez, 845 F2d 938, 942 n 6 (11th Cir 1988).
} 
dence only that the declarant is a consistent liar." ${ }^{35}$ Nonetheless, it declined to find an absolute requirement that the statement precede the motive; rather, it regarded the determinative factor to be "whether a statement has probative value apart from its repetition." $" 36$

However useful that standard may be, the Court of Appeals' application of it-later to find favor by four members of the Supreme Court $^{37}$ - was remarkably slipshod: The court's discussion centered on the conclusory declaration that it did not find persuasive Tome's underlying argument that an improper motive led to the testimony. Apart from a reference to the apparent spontaneity of A.T.'s initial statement to Rocha, however, the Court of Appeals did not explain how the prior statements made Tome's argument less persuasive. ${ }^{38}$

The Supreme Court granted certiorari limited to the single question of whether Rule 801(d)(1)(B) incorporates a "premotive" requirement. By a five-four vote, the Court held that it does. Hence, the judgment of the Court of Appeals was reversed and the case remanded.

Justice Kennedy wrote the prevailing opinion, most of which was for a majority of the Court. ${ }^{39}$ In his view, under the common

\footnotetext{
${ }^{35} 3 \mathrm{~F} 3 \mathrm{~d}$ at 350 .

${ }^{36} \mathrm{Id}$.

${ }^{37} 115 \mathrm{~S} \mathrm{Ct}$ at 710 (Breyer, J, dissenting, joined by Rehnquist, CJ, and $\mathrm{O}^{\prime}$ Connor and Thomas, JJ).

${ }^{38}$ Applying this analysis to the present case, we conclude that the district court properly admitted evidence of A.T.'s prior consistent statements under Rule 801(d)(1)(B). The record reveals that A.T. spontaneously made her initial allegation of abuse to her baby-sitter. On cross-examination, Tome implied that A.T. fabricated the allegations about her father because she wanted to live with ber mother. Although this argument does present some motive to lie, we do not believe that it is a particularly strong one. Moreover, Tome's contention would require us to believe that A.T.'s statements were the result of a calculated scheme to deceive. Yet Tome has presented no evidence that the five-year-old A.T. possessed the ability to appreciate the causal relationships inherent in the conception and implementation of such a scheme. Under these circumstances, we believe that A.T.'s consistent statements do carry probative force apart from mere repetition. We therefore find no abuse of discretion in admitting these prior consistent statements.
}

3 F3d at 351 (footnotes, citations omitted).

${ }^{39}$ Justices Stevens, Souter, and Ginsburg joined fully in the opinion. Justice Scalia concurred in the judgment and in all but one part of the opinion. He did not concur in Part IIB of the opinion, addressing the Advisory Committee Notes to the Federal Rules, because in his view that Part gave undue weight to the Notes, not merely treating them as a re- 
law rule prevailing before adoption of the Federal Rules of Evidence in 1975, a statement previously made by a witness and consistent with the witness's testimony could be introduced to rebut a charge that the witness's testimony was a product of recent fabrication or improper influence or motive-but only "if the statement had been made before the alleged fabrication, influence, or Inotive came into being." ${ }^{\prime 40}$ The Federal Rules left this premotive requirement unchanged, according to the Court, but expanded the purposes for which evidence satisfying it could be admitted. Ordinarily, a prior statement by a witness, like out-of-court statements generally, is hearsay, under both the common law and the Federal Rules, when offered to prove the truth of a matter asserted in the statement. Rule 801(d)(1), however, excludes from the definition of hearsay-and so exempts from the rule against hearsay-three categories of prior statements by a declarant who becomes a witness at trial. One of those categories, stated in subdivision (B), is for consistent statements offered to rebut a charge of fabrication or improper influence or motive. Thus, the Court concluded that the premotive requirement was simply carried over to the new, substantive use of the evidence. ${ }^{41}$

Justice Breyer dissented, joined by Chief Justice Rehnquist and Justices O'Connor and Thomas. Writing his first opimion on the Court, Justice Breyer went to some pain to emphasize that Rule 801(d)(1)(B) does not itself establish the premotive requirement: The Rule inerely accords nonhearsay treatunent to certain statements that could already be admissible for rehabilitation, and whether the statement was made before or after the motive arose appeared to have no bearing on the applicability of hearsay policy. ${ }^{42}$ The key question, rather, was one of relevance-that is, whether a prior statement consistent with the witness's trial testimony might have sufficient probative value to warrant admissibility in rebutting a charge of recent fabrication even though the stateinent was made after the inotive to fabricate arose. And the dissenters concluded that the common law statement of a premotive re-

spected and ordinarily persuasive source of scholarly commentary but according them authority in disclosing the purpose of the drafters. $115 \mathrm{~S} \mathrm{Ct}$ at 706.

to $115 \mathrm{~S} \mathrm{Ct}$ at 700 .

+1 Id at 703-04.

${ }^{42}$ Id at 707-08. Justice Breyer's atteinpt to read a hearsay policy into the Rule is discussed briefly below in note 86 and the accompanying text. 
quirement did not compel the Court to give an absolute negative answer to that question.

In most circumstances, the dissenters acknowledged, a postmotive statement would not have significant probative value $m$ rebutting a charge of recent fabrication based on an improper motive. ${ }^{43}$ But this, they contended, was not uniformly true; thus, some preRules courts, albeit a minority, did recognize that the premotive requirement was not absolute. ${ }^{44}$ The general tendency toward liberality in the admissibility of evidence reflected by the Rules, and the absence of any language in the Rules establishing such a requirement, weighed against incorporating the requirement into the Rules. ${ }^{45}$

In this case, the Court of Appeals, applying an approach similar to that advocated by the dissenting Justices, had "decided that A.T.'s prior consistent statements were probative on the question of whether her story as a witness reflected a motive to lie." This was a "factbound conclusion" that the dissenters found "no reason to reevaluate." 46 Hence, they would have affirmed the judgnient of the Court of Appeals.

Belind the narrow problem resolved by Tome lurk significant issues that escaped analysis by either the Court or the dissent. First is the basis for the traditional doctrine, significantly modified but not abrogated by the Federal Rules of Evidence, that prior statements of a witness are hearsay. This doctrine was crucial to the case, for if there were no presumptive hearsay obstacle to the admissibility of A.T.'s prior statements, there would have been no need to explore whether the statements fit within the exemption provided by Rule 801 (d)(1)(B). The Court did treat the statements as hearsay, but it did not explain wly that might be sensible; to the contrary, it rather conclusorily suggested doubt about the persuasiveness of the traditional doctrine. In domg so, it implicitly followed a line of cases in which the Court has treated crossexamination as adequate notwithstanding that the prior state-

\footnotetext{
${ }^{43}$ Id at 710 .

${ }^{44}$ Id at 708 .

${ }^{45}$ Id at 709.

${ }^{46}$ Id at 710 .
} 
ment includes propositions that the witness did not assert in her testimony. In Part II, I will challenge this treatment.

In Part III, I will focus on what are generally referred to as prior consistent statements, the subject of Rule 801(d)(1)(B). In Tome, the Court interpreted that Rule as making admissible for substantive purposes prior consistent statements that otherwise would be admissible only for rehabilitation of the witness's credibility-but it failed to articulate the distinction between these two grounds of admissibility. Without examining whether there is any substance to this distinction, it is difficult to appreciate fully what was at stake in Tome. I will argue that the distinction is an important one when the prior statement includes assertions that the current testimony does not.

With this grounding, in Part IV I will narrow the focus further and analyze, within the framework of current law, the particular issue resolved by the Court. I will conclude that the rationale underlying Rule 801(d)(1)(B) would be better served without an absolute premotive requirement. In Part V, I show how the Rule ought to be applied in a case like Tome. Finally, in Part VI I conclude with some hints as to how the case might be decided in a radically different framework that would be sensitive to two factors that appear to have had no impact on the Court's analysis: The opponent of the evidence was a criminal defendant whose confrontation rights might have been at peril, and the witness was a child.

\section{The Hindrance Issue: Examining a Witness on Assertions She No Longer Afrirms}

The basic definition of hearsay contamed in Federal Rules of Evidence 801(c) follows traditional lines:

"'Hearsay' is a statement, other than one made by the declarant while testifying at the trial or bearing, offered in evidence to prove the truth of the matter asserted."47

But why should the definition extend to prior statements made by a witness? That is, why does the italicized passage not read soinething like "otber than one made by a person who testifies subject to crossexamination at the current trial or bearing"?

${ }^{47}$ Emphasis added. 
Rule 801(d)(1) and the accompanying commentary by the Advisory Committee that drafted the Federal Rules give an intriguing indication of the complexity and difficulty of this question. Rule 801(d)(1) leaves the traditional doctrine standing, but modifies it by withdrawing from the definition of hearsay a statement that was made previously by a witness who is subject to cross-examination at the current trial or hearing and that satisfies one of three sets of conditions: The statement (a) was made under certain restrictive conditions and is inconsistent with the witness's current testimony, (b) is consistent with the current testimony, and the opponent of the evidence has opened the door by suggesting "recent fabrication or improper influence or motive," or $(c)$ is "one of identification of a person made after perceiving the person."

The Advisory Committee Note, however, does not help to explain why the Rules failed to create a broader rule classifying as nonhearsay all prior statements of a witness now subject to crossexamination. Although the Note presents arguments against maintaining hearsay treatment for such statements, the only consideration presented by the Committee in favor of hearsay treatment is its "unwillingness to countenance the general use of prior prepared statements as substantive evidence." But, though a rule agamst "prior prepared statements" easily could have been drafted, the Committee did not propose such a Rule, nor did Congress enact one. ${ }^{49}$ Moreover, the Committee confused matters by saying, "If

${ }^{48}$ Something like this might have done reasonably well:

(d) Statements which are not bearsay. - A statement is not hearsay if

(1) Prior statement by witness. The declarant testifies at the trial or hearing and is subject to cross-examination concerning the statement, unless the statement was prepared (A) for the declarant by another person, or (B) in anticipation of litigation.

${ }^{49}$ On the one hand, some prepared statements are exempted by the Rule. There is nothing in subdivisions $(B)$ or $(C)$ preventing them from applying to prepared statements. Subdivision (A), relating to prior inconsistent statements, does not, at least for the most part, cover prepared statements, because it applies only to statements made in a "proceeding" or deposition; this limitation was not included in the rule as proposed by the Advisory Commitree, however.

On the other hand, many prior statements that are not prepared fall outside the Rule:

(1) Only statements falling within one of the three subdivisions are exempt. (As originally enacted, the Rule only had two subdivisions; subdivision (C), for statements of identification, was removed from the draft presented to Congress, but added back in by subsequent legislation.)

(2) Prior inconsistent statements, even though not prepared, do not satisfy the exemption under the Rule as enacted unless they were given both "under oath subject to the penalty of perjury" and "at a trial, hearing, or other proceeding, or in a deposition." 
the witness admits on the stand that he made the statement and that it was true, he adopts the statement and there is no hearsay problem." $" 50$ This pronouncement conflicts with traditional law ${ }^{51}$ and with the text of Rule 801(d)(1) itself, which contains no such provision. ${ }^{52}$

Despite the decades-long trend against the traditional rule, prior statements made by a witness often do present serious concerns of the type generally associated with the rule against hearsay. These include the inability of the jury to observe the witness's demeanor in making the statement in question ${ }^{53}$ and, in inost cases,

(3) Prior consistent statements do not satisfy the exemption unless the opponent has opened the door by raising a charge of fabrication or improper influence or inotive.

${ }^{50}$ Notes to Rule 801(d).

${ }^{51}$ See Goings $v$ United States, 377 F2d 753, 761 (8th Cir 1967) (with respect to a statement supposedly used to refresh the witness's recollection and adopted by him: "even if the witness adopts the prior statement . . . [i]t is still a hearsay stateinent suggested to the witness rather than his own stateinent given under oath in court").

${ }^{52}$ That the witness adopts the prior statement does not in itself appear to make the statement exempt under Rule 801(d)(1) from the rule against hearsay. The prior statement may be admissible to give content to the current testimony, but that is a different matter: A jury adhering to this distinction (which is not necessarily a sensible one) could properly rely on the witness's memory as of the time of the testimony, but not the fresher memory as of the time of the statement.

${ }^{53}$ Learned Hand, in a passage quoted approvingly by McCormick and paraphrased approvingly by the Advisory Committee to the Federal Rules of Evidence, said:

If, from all that the jury see of the witness, they conclude that wbat he says now is not the truth, but what he said before, they are none the less deciding from what they see and hear of that person and in court. There is no inythical necessity that the case must be decided only in accordance with the truth of words uttered under oath in court.

DiCarlo v United States, 6 F2d 364, 368 (2d Cir 1925), quoted in John Williain Strong, gen ed, 2 McCornick on Evidence $\$ 251$, at 118 (West, 4th ed 1992), and paraphrased in Adv Com Note to Fed R Evid 801(d)(1).

But this argument fails. To the extent that demeanor is important, see generally Olin Guy Wellborn III, Demeanor, 76 Cornell L Rev 1075 (1991) (arguing that the value of demeanor evidence is far less than usually thought), it is the demeanor of the witness in Inaking the statement at issue, and in answering questions about the statement and the events or conditions it describes, that is significant. Unless the witness was videotaped when making the statement, the factfinder is likely to be virtually unable to assess her demeanor in doing so.

Consider the situation addressed by Hand, in which the prosecution wislies to prove proposition $X$, but a recalcitrant witness testifies to Not- $X$ and the prosecution then offers evidence of a prior statement inade by the witness asserting $X$. Defendant's counsel has a sound argument:

If the witness testified falsely to $X$, iny cross-examination might have created demeanor clues-sweating, eye-shifting, nail-biting-that would have been strong indications of lying. There is no reason to suppose that the witness' truthful testimony of Not- $\mathrm{X}$ will yield similarly strong signals of truthtelling - or indeed that there are similarly strong signals. Such opportunity as I have had to bolster a friendly witness does not replace the opportunity I need to confront a hostile wimess. 
the absence of an oath when the declarant made the prior statement. ${ }^{54}$ But the most important of these concerns is that, if the witness's trial testimony does not affirm the truth of all material

In another situation, which occurred in Tome, the witness testifies at trial to $\mathrm{X}$ and the prior statement is of X AND Y. Plainly, the in-court testimony cannot provide demeanor evidence with respect to $\mathrm{Y}$. (If the prior statement is only of $\mathrm{X}$, then the demeanor problem may be trivial-but so too may be the probative value of the prior statement.)

Moreover, if - as the argument in this part of the article suggests is often the case-the opponent's ability to examine the witness with respect to the prior statement and the underlying events or conditions is hindered, the probative value of the witness's demeanor in responding to such examination, as well as in making the statement itself, is also plainly diminished.

54 The Advisory Committee belittled this concern:

So far as concerns the oath, [1] its mere presence has never been regarded as sufficient to remove a statement from the hearsay category, and [2] it receives much less emphasis than cross-examination as a truth-compelling device. While strong expressions are found to the effect that no conviction can be had or important right taken away on the basis of statements not made under fear of prosecution for perjury, Bridges v. Wixon, 326 U.S. 135, 65 S.C.. 1443, 89 L.Ed. 21103 (1945), [3] the fact is that, of the many common-law exceptions to the hearsay rule, only that for reported testimony has required the statement to have been made under oath.

The assertions I have labeled [1], [2], and [3] are each true, but none of them proves very much.

[1] Of course, the presence of the oath has never been regarded as sufficient to remove from the hearsay category an out-of-court statement that has not been subjected to crossexamination, but the absence of an oath is important: Modern systems still require witnesses to take an oath or make an equivalent affirmation of obligation to testify truthfully. See, for example, Fed R Evid 603.

[2] The oath may not be as effective as cross-examination in compelling the truth, but there is good reason to believe that it reduces the incidence of false statement: A witness is likely to speak more carefully, and with a greater sense of moral responsibility, if sbe has "declare[d] that [sbe] will testify truthfully, by oath or affirmation administered in a form calculated to awaken the witness' conscience and impress the witness' mind with the duty to do so." Fed R Evid 603. Moreover, expressions such as those in Bridges, 326 US at 153-54 (to allow a defendant "to be convicted on unsworn testimony of witnesses . . . runs counter to the notions of fairness on which our legal system is founded"), suggest that the value of the oath lies not only in the impact it bas on the witness but also (at least with respect to criminal prosecutions) in its very formality, in establishing an acceptable setting for making statements with testimonial intent. The sense that accusing witnesses are forced to take the matter of accusation with utmost seriousness may be important in making criminal convictions acceptable; see generally Charles Nesson, The Evidence or the Event? On Fudicial Proof and the Acceptability of Verdicts, 98 Harv L Rev 1357 (1985) (emphasizing the importance of public acceptability of verdicts)-especially if the oath is perceived to restrain false statement.

[3] A similar statement could be made with respect to cross-examination; that is, the hearsay exemption for prior testimony is the only one that requires the declarant to bave been cross-examined. A more fruitful way of looking at the matter is this: If a statement was made under oath and subject to a satisfactory opportunity for adverse examination, it is exempted, as prior testimony, from the rule against hearsay if the defendant cannot testify live at the present proceedings. See Fed R Evid 804(b)(1). All the other hearsay exemptions address situations in which either or both of these conditions do not apply. Note also that Rule 801(d)(1)(A), as eventually passed by Congress, does require an oath for prior inconsistent statements-but does not require cross-examination. 
propositions asserted in the prior statement, the opponent's ability to cross-examine the witness with respect to those propositions is severely hindered as compared to what it would be if the witness liad affirmed those propositions at trial. Sucl a hindrance is, of course, a substantial factor in determining whether the prior statement sliould be excluded, but it is not necessarily dispositive of that question. I sliall discuss the hindrance here, and sliall address the admissibility question briefly in Parts $V$ and VI.

In discussing the hindrance question, and generally througliout this article, I will focus on the situation in which both the trial testimony of the witness and the prior statement of that witness are offered by a criminal prosecutor. ${ }^{55}$ This is, of course, only one setting for the introduction of prior statements, but it is the setting of Tome, and it is one in which the hindrance problem may be quite stark.

At the outset, it is important to einphasize that the opponent is probably not substantially prejudiced in his ability to crossexamine the witness if she testifies to the entire substance of lier prior statement: She can be cross-examined effectively with respect to whatever she said before, because sle is also asserting it from the witness stand. At the same time, lowever, this congruence between the prior statement and the current testimony makes it doubtful, given the testimony, that there is any need for the prior statement. Of course, in some circumstances the timing of the prior statement inay inean that the statement lias significant probative value even given the current testimony. It inay be that the prior statement was made before the emergence of some improper influence that might have deflected the witness from the truth.

\footnotetext{
${ }^{55}$ Thus, I am simplifying somewhat by speaking of cross-examination rather than adverse examination, and also by assuming that the opponent of the prior statement is the opponent of the party who put the witness on the stand.

It may be that the prior statement is offered against, rather than by, the party who called the witness to the stand; this sometimes happens if the prior statement is inconsistent with the current testimony. In such a case, the adverse examination would be on redirect. (Note that often the prior mconsistent statement is introduced by the party who put the witness on the stand because the witness's testinony has been less favorable than the prior statement to that party.)

Also, in some cases, like Tome, the prior statement is introduced, through another witness, after the declarant lias left the stand. In such a case, under custoinary procedures, if the party opponent wanted to question the declarant about the prior statement he would usually have to recall her to the stand as his own witness. Alternatively, the party opponent might anticipate proof of the prior statements and present them to declarant while she is still on the stand. See text accompanying note 81 .
} 
And it may be that at trial the witness has a substantially weaker memory of the described event than she did when making the prior statement.

The problems are reversed when the prior statement asserts information that the current testimony does not. This disparity im content might arise in either of two basic ways. First, it might be that the prior statement is materially inconsistent with the witness's trial testimony, and so presumably introduced by the prosecution because that testimony disappointed it. Second, as in Tome, the trial testimony may be consistent in material respects with the prior statement, but less complete. ${ }^{56}$ Whichever way it arises, the disparity in content makes it likely that the prior statement has significant probative value, even given the current testimony. But the same disparity may significantly hinder the opponent's ability to cross-examine.

This last suggestion seems to be in accordance with a declaration made by the Supreme Court thirty years ago, in Douglas $v$ Alabama, that "effective confrontation" of a witness "was possible only if [the witness] affirmed the statement as his." ${ }^{57}$ But it also conflicts squarely with the line taken by the Advisory Committee for the Federal Rules ${ }^{58}$ and, consistently over the last quarter century, by the Court as well. In California $v$ Green, ${ }^{59}$ the Court held that a criminal defendant's opportunity to cross-examine the declarant of a statement is not rendered constitutionally inadequate by the fact that the declarant testifies at trial inconsistently with the prior statement. ${ }^{60}$ The next year, in Nelson $v$ O'Neil, ${ }^{61}$ the Court went further, running over Douglas by holding

${ }^{56}$ A.T.'s prior statements included a wealth of information that was not conveyed by her trial testimony, which, for all the questions it took to secure, was rather skimpy in describing the alleged assault. Her prior statements, but not ber trial testimony, included assertions (among others) that Tome's sexual assaults were repeated, and that he had kissed her all over, including her vaginal area, put his fingers in her vagina, touched her breasts and her bottom, asked her to touch his penis, and dragged ber around the house.

${ }^{57} 380$ US 415, 420 (1965). Douglas also said that the declarant "could not be crossexamined on a statement imputed to but not admitted by him." 380 US at 419 .

58 "Nor is it satisfactorily explained why cross-examination cannot be conducted subsequently with success." Note to Rule 801(d)(1). The Advisory Committee's view is analyzed further in notes 77-79 and accompanying text.

${ }^{59} 399$ US 149 (1970).

${ }^{\circ 0}$ This was the holding of Green, even if it did not represent the actual facts of the case. The Court analyzed the case as if the witness testified inconsistently with the prior state- 
that there was no constitutional problem, though the declaraut not only testified inconsistently with the prior statement, but denied making it. ${ }^{62}$ And seventeen years after Nelson, in United States $v$ Owens, ${ }^{63}$ the Court extended Green in another direction, holding that, under both the Confrontation Clause and Rule 801(d)(1), the opportunity to cross-examine is not rendered inadequate by the fact that at trial the witness no longer renembers the event described in the prior statement.

In effect, Green, Nelson, and Owens all concluded that crossexamination with respect to the prior statement was not only adequate, but hardly necessary. In the Court's view, because at trial the witness no longer asserts a proposition that she asserted in the prior statement, the opponent has essentially achieved the benefit of cross-examination with respect to that proposition. ${ }^{64}$

ment, and held that this did not render cross-examination constitutionally deficient. 399 US at 153-64. Only toward the end of the case did the Court seem to notice that in fact the witness claimed a failure of memory "and hence failed to give any current version of the more important events described in his earlier statement." Id at 168. The Court recognized that this factor raised an additional issue, and so remanded the case, id at 168-70; that issue was resolved in the Owens case, described below.

6402 US 622 (1971).

${ }^{62}$ Nelson distinguisbed Dotuglas on the ground that, in Douglas, the declarant refused on the basis of the privilege against self-incrimination to answer any substantive questions.

In Nelson, defense counsel did not cross-examine the declarant at all. Contrary to the Court's implication, however, this does not suggest that the declarant's testimony left the defendant in a strong position; he was, after all, convicted. Rather, defense counsel presumably concluded that cross-examination of a witness who had just provided favorable testimony was unlikely to do much good.

684 US 554 (1988).

G In Green, 399 US at 159, the Court said:

The most successful cross-examination at the time the prior statement was made could hardly hope to accomplish nore than has already been accomplished by the fact that the witness is now telling a different, inconsistent story, and-in this case-one that is favorable to the defendant.

In Nelson, 402 US at 628-29, the Court said:

Had Runnels in this case "affirmed the statement as his," the respondent would certainly have been in far worse straits than those in which he found himself when Runnels testified as he did. ...

The short of the matter is that, given a joint trial and a common defense, Runnels's testimony respecting his alleged out-of-court statement was more favorable to the respondent than any that cross-examination by counsel could possibly have produced, had Runnels "affirmed the statement as his."

And in Owens, 484 US at 561-62, the Court said:

[L]imitations on the scope of examination by the trial court or assertions of privilege by the wituess may undermine the process to such a degree that ineaningful cross-examination within the intent of the Rule no longer exists. But that effect 
For several reasons, I believe this analysis is misguided.

1. Blunting the Tools. Suppose the prosecution wishes to prove that the defendant, Dennis, was at a particular restaurant, The Scene, on a given niglit. If a witness, Whitney, testifies on direct examination, asserting proposition DENSCENE (that Dennis was at The Scene on the night in question) purportedly from her current memory, Dennis has an uncluttered opportunity to confront her. Through counsel, he might ask her questions that appear to have some relation to DENSCENE. For example, he might ask her whether GAILSCENE-the proposition that Gail, Dennis's girlfriend, was at The Scene at the same time-is true. If the witness does not in fact have a clear memory that DENSCENE is true, but she is eager to have the jury believe that it is, this question might put her in an awkward position. For all she knows, if she affirms GAIILSCENE, Dennis might be able to show that GAILSCENE is false-perhaps there is a solid alibi for Gail-suggesting that the same testimonial failure that led to Whitney's inaccurate assertion of GAILSCENE might have led to her assertion of DENSCENE. And for all Whitney knows, if she denies GAILSCENE, Dennis might be able to demonstrate that it is highly unlikely that if DENSCENE is true GAILSCENE is false; perhaps Dennis and Gail are known to have been together earlier and later that night, and it seems highly implausible that Dennis would have dropped Gail off before going to The Scene and picked her up later. Finally, if she attempts to avoid the dilemma by denying ability to remember whether or not GALSCENE is true, it might be that Dennis can demonstrate that it is highly unlikely that she would remember DENSCENE and not remember GAILSCENE; perliaps Gail was wearing a bright red dress, she and Whitney were good friends, and Dennis's presence at The Scene would likely have appeared utterly unremarkable to Whitney at the time, but Gail's presence was unusual.

Of course, Whitney might guess right when asked, "Was Gail there with Dennis?" She might assert what is in fact true, or at least what Dennis cannot effectively disprove. But Dennis has at least had the opportunity to lay the trap. If he lays enough of them,

is not produced by the witness' assertion of memory loss-whicb . . . is often the very result sought to be produced by cross-examination, and can be effective in destroying the force of the prior statement. 
and Gail is not testifying truthfully in asserting her clear memory of DENSCENE, she is likely to fall into one of them.

The predicate for all this, though, is that Whitney asserts DENSCENE just before cross-examination. If Whitney denies DENSCENE on direct examination but her prior assertion of DENSCENE is admitted, cross-examination is unlikely to have the same effectiveness. Suppose the defense asks Whitney whether GAILSCENE is true and she denies it. Now, even if NOT-GAILSCENE, or the conjunctive proposition DENSCENE AND NOT-GAILSCENE, appears highly unlikely, the prosecution has a ready explanation-that the same testimonial failure that led to an inaccurate demal of GAILSCENE on cross led to an inaccurate demal of DENSCENE on direct. Similarly, if Whitney's prior statement of DENSCENE is admitted after she testifies on direct that she cannot remember whether or not DENSCENE is true, her testimony on cross that she cannot remember whether or not GAILSCENE is true will help Dennis little or not at all. If it does not already appear strange that Whitney remembered DENSCENE at the time of the earlier statement but not at trial, it will probably not appear strange that she does not renember GAILSCENE at trial. The prosecution is not put in the position of arguing that Whitney remembered the more forgettable and forgot the more memorable; a single "gauzy cloak" of forgetfulness ${ }^{65}$ over the whole matter will provide a full explanation.

2. Denial of the Possibility of Complete Nullification. When a witness testifies on direct to ASSERTION, the best result the crossexaminer can hope to achieve is a repudiation of the direct testimony-a statement by the witness saying, in effect, "Although I just testified to ASSERTION on direct, I recognize now that I cannot affirm that it is true." This might occur if the witness follows along with the type of examination outlined above: "Gee, I have no idea whether or not CONSEQUENTIAL DETAIL is true, and I guess that if ASSERTION were true then I would know that CONSEQUENTIAL DETAII is true, so I suppose I was mistaken in asserting ASSERTION." Nearly thirty years ago, in an extremely perceptive opinion in Rubala $v$ Roby, ${ }^{66}$ the Supreme

${ }^{65}$ California Retail Liquor Dealers Assn. v Midcal Aluninum, Inc., 445 US 97, 106 (1980) ("a gauzy cloak of state involvement over what is essentially a private price-fixing arrangeinent").

${ }^{66} 379$ Mich 102, 124-28, 150 NW 2d 146, 156-58 (1967). 
Court of Michigan showed how cross-examination might lead to this result. When this happens, as the Rubala court pointed out, the witness's direct testimony of ASSERTION retains little probative value; it would almost certainly be struck and not allowed to support a verdict, at least if the witness did not again affirm ASSERTION on redirect. ${ }^{67}$ Presumably the same result would obtain if the witness were allowed to testify on direct by adopting a prior statement in all its details, and then on cross repudiated it all: The recantation on cross of everything the witness had said on direct would mean that the "original recanted version no longer stands as substantive evidence."

But now suppose the starting point of the examination is that, although the witness once said ASSERTION, she says so no longer. The proponent will argue that the witness accurately stated ASSERTION at the earlier time and that some influence-failure of memory, perhaps, or bias - intervened to prevent her from stating ASSERTION at trial. If that argument is plausible, the prior statement retains probative value with respect to ASSERTION. And if for this reason the prior statement is admitted to prove ASSERTION, that means by definition that the opponent cannot hope to achieve the optimal result, nullification of a statement just made. "If I had been able to cross-examine immediately after the witness stated ASSERTION," the opponent can argue, "I might have secured a complete retraction that would have nullified the effectiveness of the current testimony. I can't do that now." Rather, the admissibility of the prior statement means that the jury is told, in effect, "You have two different versions before you, the prior statement and the current testimony. Consider them both and draw the best inference you can." 68

Perhaps the lost opportunity to the cross-examiner seems trivial, the mere denial of a faint possibility of a "final triumphal flourish"

67

When a cross-examiner on timely cross-examination succeeds in getting the witness to change his story, the integrity of the recantation is apparent, and bis original, recanted version no longer stands as substantive evidence. If the only evidence of an essential fact in a lawsuit were a statement made from the witness stand which the witness himself completely recanted and repudiated before he lefr the witness stand, no one would seriously urge that a jury question had been made out.

379 Mich at $128,150 \mathrm{NW} 2 \mathrm{~d}$ at 158.

${ }^{68}$ The substantive admissibility of prior inconsistent statements was defended by McCormick on just this ground. Charles T. McCormick, Evidence $\$ 39$, at 75 (West 1954). 
at the conclusion of cross-examination..$^{69}$ It is true, of course, that most witnesses do not make full recantations of assertions they have just made on direct. But the fact is that the witness bas testified in a way at variance with the prior statement, failing to assert a proposition asserted in the prior statement; if the witness had made the assertion in direct testimony, and then disclaimed it on cross, the assertion would have been nullified.

3. A Buffer Around the Statement. The time gap between the prior statement and the trial testimony may provide a ready explanation for why the witness does not testify at trial to the substance of the statement. The witness inay, for example, have suffered a memory loss because of trauma ${ }^{70}$ or because of the more ordinary passage of time, she may have been intimidated into silence, or she may have been exposed to some bias-creating motive. ${ }^{71}$ But showing such intervening influences is not generally to the advantage of the party opposing the proposition asserted in the prior statement.

To the contrary, it may be the proponent who wants to demonstrate these intervening influences. ${ }^{72}$ If they tend to lead the declarant away from, rather than toward, the truth, they generally will tend to make more probable an account in which the events occurred as the proponent contends, the mitial statement accurately reported the events, and then a testimonial failure occurred that prevented the witness from recounting the full substance of the earher statenient at trial. ${ }^{73}$

\footnotetext{
${ }^{69}$ Letter of Standing Committee on Rules of Practice and Procedure and Advisory Coinmittee on Rules of Evidence to Sen. James O. Eastland, Chairman of Senate Committee on the Judiciary, May 22, 1974, quoted in Jack B. Weinstein, Margaret A. Berger, \& Joseph M. McLaughlin, 4 Weinstein's Evidence 801-15 (Matthew Bender, 1995) (hereinafter "Joint Committee letter").

${ }^{70}$ That was quite clearly the situation in Owens, in which one Foster, the victim of the vicious hattering with which Owens was charged, was unable at trial to identify his assailant, though he had previously made a statement identifying Owens.

"All these, except perhaps the last, are possible explanations of A.T.'s failure at trial to repeat the full substance of her earlier statements.

${ }^{72}$ Ir is thus laughable to think, as the Court suggested, that Owens "destroy[ed] the force" of Foster's statement by showing Foster's memory loss, or that he achieved "the very result sought to be produced" in his cross-examination of Foster, 484 US at 562; Owens was, after all, convicted largely on the basis of the statement.

${ }^{73}$ Thus, McCormick on Evidence, $\$ 251$, in a passage that originated with the second edition (Edward Cleary, gen ed, West, 1972), cominents with respect to State $v$ Saporen, 205 Minn 358,285 NW 898 (1939), a case often cited in favor of the traditional view that prior statements of a witness are hearsay, that
} 
Consider Tome itself. A.T. seemed to acknowledge at one point during her testimony that she made some of the prior statements, but the prosecutor did not ask her to affirm their truth to the extent that they went beyond her in-court testimony. ${ }^{74}$ It seems unlikely that Tome would have been able effectively to crossexamine A.T. with respect to her prior statements. ${ }^{75}$ Tome might, of course, be able to explore her lack of memory at the time of trial and her inability to testify articulately at trial. But this would not suggest that her previous articulations of sexual abuse, made in different circumstances a substantial time before, were concoctions of failed memory. Indeed, the decay of memory in the period leading up to trial, which Tome could easily demonstrate, has no obvious bearing on what he would want to show-that in the period leading up to the statements A.T., whether consciously or not, fabricated recollections. Rather, einphasizing A.T.'s inability to testify fully at trial would simply play into the prosecution's hands, given that the prior statements included information helpful to the prosecution and not affirmed by her trial testimony: It would make more likely a scenario in which the events occurred, slie made the

the witness did change his story very suhstantially; rather than hardening, his testimony yielded to something between the giving of the statement and the time of testifying. This appears to be so in a very high proportion of the cases, and the circumstances most frequently suggest that the "something" which caused the change was an improper influence.

This is not really an argument that cross-examination of the declarant is adequate, or that the statement should not be considered hearsay. Rather, it is an argument that in the run of cases the prior statement should be deemed reliable. But surely this is too broad a generalization to support wholesale exemption of all prior statements from examination under the law of hearsay, especially when confrontation rights are at stake.

Indeed, in Saporen itself, the circumstances did not suggest that an improper influence had arisen between the time of the statement and the time of the testimony; on the contrary, the witness contended that he had made the prior statement, which was more favorable to the prosecution than was his current testimony, in response to threats. $205 \mathrm{Minn}$ at 360, $285 \mathrm{NW}$ at 900 .

Interestingly, then, the Advisory Committee for the Federal Rules of Evidence, while defending a doctrine similar to that espoused by McCormick, took a far different approach to cases like Saporen. See notes 77-79 and accompanying text.

${ }^{74} \mathrm{~T}$ 158-59.

${ }^{75}$ Note that Rule 801 (d)(1) requires that the witness be "subject to cross-examination concerning the statement," not " . . concerning the subject matter of the statement." It would be possible to construe the two formulations so that the second one, but not the first, demands that the witness remember the subject matter of the statement, not merely the statement itself. On the other hand, arguahly the first formulation but not the second demands that the opponent have an opportunity to examine the witness after the prior statement has been presented to the jury. 
statements accurately describing them, and subsequently forgot them or became intimidated.

Sometimes at trial (not in Tome), the witness not only fails to confirm the entirety of the prior statement, but repudiates it and supplies a reason for making the statement notwithstanding its inaccuracy. ${ }^{76}$ The drafters of the Federal Rules, arguing unsuccessfully in favor of a general exemption for prior inconsistent statements, contended that this result "is cross-examination beyond the dreams of avarice." 77 But that is plainly not so-as demonstrated by the convictions achieved in notable cases by prosecutors relying on prior accusatory statements repudiated from the witness stand by the accusers. ${ }^{78}$ Indeed, this argument exposes a certain Janus-like quality in the arguinents for the adequacy of later crossexamination. Is the point, as the drafters and the Supreme Court have contended, that the inconsistent testimony itself satisfies the need for cross-examination by exposing the weakness of the prior statement? Or is it the contrary point, advocated by the editors of McCormick on Evidence, that the prior statement is too valuable to lose because the inconsistency is likely attributable to a laterarising improper influence? ? $^{79}$

Certainly the facts might appear to fit the McCormick portrayal-but this is not necessarily an argument for admissibility. The jury may be persuaded that the prior accusatory statement was the true one, and that the improper influence was brought to bear by the accused between the time of the prior statement and the time of trial, leading the witness not only to retract the prior statement but to concoct an explanation as to why she made that statement. Adverse examination of the witness at the time of trial, when she is making and explaining the repudiation, will plainly be of little avail in dispelling such a conclusion. The sitnation is much

\footnotetext{
${ }^{76}$ For example, in Saporen, the witness said that he had inade the earlier statennent in

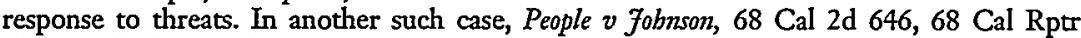
599, 441 P2d 111 (1968), rejected in California v Green, 399 US 149 (1970), the witnesses, the wife and daughter of the defendant, contended that previous personal interests of theirs had led them to accuse hin falsely of sexual inolestation. The Advisory Committee said that these cases, which argued for the inadequacy of the later cross-examination, "in fact demonstrate quite thorough exploration of the weaknesses and doubts attending the earlier statement." Note to Rule 801(d)(1).

${ }^{77}$ Joint Committee letter, cited in note 69.

${ }^{78}$ See Saporen and Fobnson, discussed in note 76.

${ }^{79}$ See note 73 .
} 
as if there were two witnesses. One is in court, subject to examination, casting doubt on the prior statement, and so outwardly helping the accused, but in a suspicious manner wholly unpersuasive to the factfinder. The other, the one doing the damage, is not in court and is impervious to adverse examination. ${ }^{80}$

Put another way, cross-examination in this circumstance is somewhat like pushing on a string; the task cannot be done most effectively unless it meets resistance.

4. Enbanced Cost and Risk. Tome illustrates an additional obstacle that some opponents confront. Had A.T. testified on direct to the substance of the prior statements, then presumably Tome's counsel would not have foregone the opportunity in the course of her cross-examination, which followed immediately, to question A.T. about those assertions. But this was not the situation. A.T.'s prior statements were introduced through other witnesses after A.T. had left the stand; she herself gave conflicting and sometimes ambiguous testimony, on cross and redirect examination, as to whether she had even made the statements or remembered doing so. ${ }^{81}$ Thus, to examine A.T. about the substance of the prior statements, which added considerable detail not in her testimony, counsel would have had to present those details to her. This she could have done in either of two basic ways. First, while A.T. was on the stand as the prosecution's witness, counsel could have anticipated the testimony of the other witnesses, reciting its substance to her-a move that would have been utterly self-defeating if

\footnotetext{
${ }^{80}$ As the Rubala court suggested, the fact that the witness is no longer asserting the proposition at issue may force the opponent to treat her as more friendly than hostile. ("The would-be cross-examiner . . . is left with no cboice but to become the witness's friend, protector and savior." 379 Mich at 125, 150 NW2d at 156.) And this means that "the real nature of cross-examination" is lost:
}

Cross-examination presupposes a witness who affirms a thing being examined by a lawyer who would have him deny it, or a witness who denies a thing being examined by a lawyer who would have him affirm it. Cross-examination is in its essence an adversary proceeding. The extent to which the cross-examiner is able to shake the witness, or induce him to equivocate is the very measure of the crossexaminer's success.

*** If [the witness] refuses to adopt his prior statement as true, there can be no adversary cross-examination upon it. If he refuses to affirm, no question can be put to him which would shake his own confidence in his affirmation.

379 Mich at $124,150 \mathrm{NW} 2 \mathrm{~d}$ at 156.

${ }^{81} \mathrm{~T} 152-53,158-59$. 
Tome still hoped to keep any of that testimony away from the jury. Alternatively, counsel might have recalled A.T. to the stand after the other witnesses testified-a move that the jury might have regarded as desperate and overbearing - and reviewed that testimony. Either way, counsel would have had to give the prosecution's most vivid evidence an extra run-through in front of the jury. And if her examination of A.T. on these details fell flat, a very predictable prospect given A.T.'s performance on the stand, Tome would probably end up worse off than if she had never tried: The jury would likely have seen that, by presenting A.T. with the prior statements, counsel was going out of her way to dig her own hole, and failure to dig herself out might have been particularly damaging.

Not surprisingly, defense counsel, presumably reckoning that the risk outweighed the potential benefit, did not attempt to pursue the matter.

I do not mean to suggest that introduction of a prior statement made by a witness who no longer asserts all its substance necessarily leaves the party opponent in a helpless position; he is presumably better off than if a credible witness tells a convincing story that is impervious to cross-examination. Nor do I suggest that prior statements in this circumstance ought generally to be excluded; whether exclusion is appropriate does not depend exclusively on whether the opportunity for cross-examination is satisfactory. But what I have tried to show is that the opportunity for cross-examination is substantially hindered in this situation-and that the Supreme Court has failed since Green to recognize this.

The natural response to this problem, under the prevailing structure of the law, is to classify such prior statements as hearsay. Within that structure, the traditional classification of prior statements as hearsay makes more sense than was recognized by the Advisory Committee, which in large part retained it, or by the Supreme Court, which even in the extreme circumstances of Owens refused to recognize how the opportunity for effective crossexamination was hindered. But placing a statement within the basic definition of hearsay in Rule 801(c) is only the first step in determining whether it is excluded by the Rules as hearsay. I now turn to the exemption at issue in Tome. 


\section{Understanding the Rule on Prior "Consistent" STATEMENTS}

Rule 801(d)(1)(B) exempts from the rule against hearsay a prior statement by a declarant who is a witness at the trial or hearing, subject to cross-examination concerning the statement, if the statement is "consistent with the declarant's testimony and is offered to rebut an express or implied charge against the declarant of recent fabrication or improper influence or motive." The structure of the Rule has proved confusing. In two respects, thinking about it might be simplified by replacing the first eight words in this quotation by the word "admissible."

First, this change emphasizes the essential nature of the rule, which some judges have misunderstood: If a prior statement is admissible on the limited ground stated in the Rule ("to rebut an express or implied charge ..."), then the rule against hearsay should not bar admission of the statement to prove the truth of a matter that it asserts. ${ }^{82}$

Second, consistency is a misleading standard. If a statement is admissible for the described rebuttal purpose, then it should be deemed consistent within the meaning of the Rule. ${ }^{83}$ The prior

${ }^{82}$ The Advisory Committee Note stated this point rather clumsily: "Prior consistent statements traditionally have been admissible to rebut charges of recent fabrication or improper influence or motive but not as substantive evidence. Under the rule they are substantive evidence." Adv Comm Note to Rule 801(d)(1)(B). But not all prior consistent statements are substantive evidence under the Rule, just as not all were traditionally admissible for rebuttal purposes.

Some courts have been confused by the structure of the Rule because it appears to address only a nonhearsay use of the prior statement. See, for example, United States v Casoni, 950 F2d 893, 905 (3d Cir 1991) (stating that "the rule is confusing" because if a statement is offered to rebut a charge of recent fabrication " $i t$ is then not offered to prove the truth of the matter asserted"). But placement of the Rule within the definition of hearsay seems to make clear the framers' intention that if the prior statement is offered (or, in my view, admissible) for the designated nonhearsay purpose, then the Rule also makes it exempt from the rule against hearsay.

${ }^{83}$ Of course, mere logical consistency-that is, the ahsence of logical inconsistency-is insufficient to invoke the rule. The statements " $M y$ father abused me" and "It is raining today" are perfectly consistent, but the fact that the witness asserted one of them does not suggest that she was telling the truth in asserting the other.

In State v Collins, 1989 Ohio App LEXIS 452, the court did attempt to find independent neaning for the word "consistent" as used in Ohio Rule 801(d)(1)(B), which is identical to the federal rule. Purporting to rely on a dictionary search, the court concluded that "the concept of agreement" is the central core of the word's meaning in the rule, so that "statements to he consistent must be about the sanie subject matter" and "statements concerning two differing subjects [such as, presumably, the abuse and rain statements presented just above] are simply foreign to each other." But the court also said, after pointing out that the prior statement in that case included matter foreign to the testimony, "Since the concept 
statement may have the prescribed rebuttal effect if it contains precisely the same information as the current testimony, somewhat more (as in Tome) or less, or even if there are logical mconsistencies between the two. ${ }^{84}$

As emphasized by Justice Breyer's dissent, rebutting a "charge of recent fabrication or improper influence or motive" is not the only way in which a prior consistent statement may tend to rehabilitate a witness's testimony. ${ }^{85}$ Why, then, was it the only form of rehabilitation mentioned by Rule 801(d)(1)(B)? Justice Breyer's attempt to develop a rationale is unpersuasive. ${ }^{86}$ The most plausible explanation appears to be that this was just a careless bit of drafting. The intention of the drafters seems to have been that if a

of a prior consistent statement is primarily directed to rehabilitation of a witness charged with having fabricated his testimony, the testimony [of the prior statement] as admitted could not satisfy this purpose."

${ }^{84}$ United States $v$ Casoni, $950 \mathrm{~F}$ d 893, 896, 903 (3d Cir 1991) (holding that prior statements of witness "ffall within Rule 801(d)(1)(B)'s definition of prior consistent statements because the rule does not require them to be consistent in every detail with [the witness's] testimony at trial"; the prior statements and the current testimony were indeed inconsistent in some details); United States v Vest, 842 F2d 1319, 1329 (1st Cir 1988) (holding prior statement "sufficiently close" to the testimony to be covered by the Rule, notwithstanding "the one inconsistency"; "a prior consistent statement need not be identical in every detail to the declarant's ... testimony at trial").

Suppose Alfred testifies against Brenda, describing some wrongdoing that he says she committed. Brenda brings out that a year before trial Alfred developed a terrible grudge against Brenda when Brenda divorced Alfred's brother. Alfred or Charles might then testify against Brenda that several years hefore that, while family serenity reigned, Alfred had nuade a casual statement to Charles describing the wrongdoing; admissibility of the statenent on this basis will not ordinarily be defeated on the ground that in the prior statenient Alfred said the deed occurred on June 23 and in the current testimony he placed it on June 24.

${ }^{85} 115 \mathrm{~S} \mathrm{Ct}$ at 707. Perhaps noost importantly, a prior statement that reflects a significantly fresher inemory than does the current testimony might help dispel the contention that the testimony is a product of faulty nienory. The logic here is inuch the saine as in the case of a premotive statement offered to rebut a charge of recent fabrication: A statement nuade before the alleged testimonial failure suggests strongly that the failure does not account for the testimony. Indeed, perhaps "fabrication" could be construed to reach the case of false testimony created by faulty nieniory-but that would be a stretch.

${ }^{8} \mathrm{He}$ suggested that (1) jurors have trouble distinguishing between substantive and rehabilitative use of the type of statement covered by the Rule, (2) the Rule was a concession to this difficulty, and (3) "[i]f there was a reason why the drafters excluded from Rule 801(d)(1)(B)'s scope other kinds of prior consistent statenients (used for rehabilitation), perhaps it was that the drafters concluded that those other statements caused jury confusion to a lesser degree." $115 \mathrm{~S} \mathrm{Ct}$ at 707-08. The first proposition is unquestionably correct, but the third is, as Justice Breyer seeined to recognize, totally speculative; he suggested no reason to believe that it is true, and I doubt that there is. (The second proposition nuay be descriptively accurate, but as I show later in this part there are considerations not dependent on the effectiveness of a jury instruction that weigh in favor, within the prevailing structure of hearsay law, of inaintaining the distinction between substantive and rehabilitative use.) 
prior consistent statement is admissible for rehabilitation it should be admissible substantively - that is, to prove the truth of what it asserts-notwithstanding the rule against hearsay. The language used by the Rule describes the most common, but not the exclusive, situation in which a prior consistent statement might be admitted for rehabilitation.

Of course, this language, however careless, does limit the reach of the Rule. Only statements described by the Rule are exempted by it from the rule against hearsay. But the Rule should not be understood to state the bounds of the circumstances in which a prior statement consistent with a witness's testimony is admissible to support the credibility of the witness. The Rule would be oddly placed to set the bounds on rehabilitative use. It is in the Article dealing with the law of hearsay, and is expressly part of the defimition of hearsay, not in the Article that deals with impeachment and support of witnesses. Moreover, it is clearly a rule designed to loosen an old restraint on admissibility, not to impose one. Unfortunately, some courts have interpreted the Rule to set the bounds of admissibility of prior consistent statements for rehabilitative as well as substantive purposes. ${ }^{87}$ The issue was not posed by Tome, but some loose language in the majority opinion might suggest-unintentionally, I believe-that this was the Court's view. ${ }^{88}$

Why should, or should not, a prior consistent statement admissible for the rebuttal purpose described by the Rule (or for any other rebuttal purpose) also be admissible substantively-that is, to prove the truth of what it asserts? To ask this question brings into relief another perplexing question: What (if anything) is the

${ }^{87}$ See John William Strong, gen ed, 2 McCormick on Evidence $\$ 251 \mathrm{nn} 29-30$ and accompanying text (West, 4th ed 1992) (collecting authorities going both ways).

${ }^{88}$ The Court seems to have spoken of Rule $801(\mathrm{~d})(1)(B)$ as a rule of rebuttal testimony. See 115 S Ct at 702 ("if the drafters of Rule 801(d)(1)(B) intended to countenance rebuttal along that indirect inferential cbain"), 705 ("The Rule permits the introduction of a declarant's out-of-court statements to rebut a charge of recent fabrication or improper influence or motive only when ..."). On the other hand, the latter statement is prefaced by this statement: "Our holding is confined to the requirements for admission under Rule 801(d)(1)(B)." The Court's view seems to have been that the Rule implicitly (via the premotive requirement) limits the circumstances in which a prior statement might be admitted for the rebuttal purpose specified by the Rule itself, but not for other rebuttal purposes. Compare $115 \mathrm{~S} \mathrm{Ct}$ at 707 (Breyer, J, dissenting: "The majority is correct in saying that there are different kinds of categories of prior consistent statements that can rehabilitate a witness in different ways...."). 
difference between the two grounds of admissibility? I think the best answers to these questions, like the issue of the adequacy of cross-examination, depend very much on whether the prior statement introduces information not contained in the current testimony.

Consider first the situation in whicl the prior statement inerely asserted a proposition, ACCUSATION, that is contained in the current testimony; according to the party opponent, soine improper influence caused the witness to testify to ACCUSATION, but the prior statement, having been inade (to keep inatters simple) before the influence arose, suggests that this is not so. Even in this situation, there is an epistemological difference between admissibility of the prior statement only to rebut the charge of improper influence, on the one liand, and to prove the truth of the inatter that the statement asserts, on the other-but it is a narrow and rather rickety one. Consider three inutually exclusive and exhaustive propositions:

(1) Absent the intervention of the improper influence, the witness would not have testified to ACCUSATION at trial.

(2) At the time of the prior statement, the witness believed ACCUSATION to be true [which inakes ACCUSATION inore likely true], and even absent the intervention of the inproper influence she would have testified to ACCUSATION at trial.

(3) At the time of the prior statement, the witness did not believe ACCUSATION to be true [which makes ACCUSATION less likely true], but even absent the intervention of the inproper influence she would have testified to ACCUSATION at trial.

Admissibility only for the rebuttal purpose can be taken to mean that the jurors can use the prior statement to evaluate the probability of proposition (1) against propositions (2) and (3), ${ }^{89}$ but not to evaluate the probability of proposition (2) against proposition (3).

\footnotetext{
${ }^{89}$ Even though the statement was made before the improper influence arose, it does not prove absolutely that the witness would bave testified to ACCUSATION at the time of trial absent the influence. It could be that at the tine of the statement the witness was subject to some other influence, not as strongly active at the time of trial, tending to lead ber to state ACCUSATION. It could be, for example, that the witness states ACCUSATION at the earlier time, believing (whether accurately or not) that ACCUSATION is true, but by the time of trial bas no recollection of ACCUSATION, and absent the improper influence would not testify as to it.
} 
That this difference is logically coherent is perhaps the best that can be said for it. Even assuming a jury-or a court-can understand the distinction, adherence to it is improbable; neither is likely to cramp its reasoning so artificially. ${ }^{90}$

Perhaps more important, no good purpose is served by such a restriction. Recall from the last section that, if the substance of the prior statement is included in the current testimony, the party opponent is not genuinely hindered in cross-examination by the fact that the prior statement was made some time before the current testimony. If the prior statement is nevertheless to be excluded, the only sound reasons would be to induce the presentation of the witness's current testimony and, in light of that testimony, to avoid wasting time by presentation of evidence that has little incremental value. But the witness has given her current testimony, and even before the charge of improper influence is made the prior statement may have significant incremental value in that it reflects a substantially fresher memory than does the current testimony. Once the charge is made, the question is easy: The statement will be heard and considered by the jurors, at least for the rehabihitative purpose, and no time is saved by putting artificial shackles on them. Moreover, the party opponent, having suggested the intervention of an improper influence, is hardly in a position to complain if the jury is allowed to consider whether an earher statement by the witness of ACCUSATION tends to make it more probable that the witness believed ACCUSATION when she asserted it, and therefore also that ACCUSATION is true. As the Advisory Committee said, "The prior statement is consistent with the testimony given on the stand, and, if the opposite party wishes to open the door for its admission in evidence, no sound reason is apparent why it should not be received generally." 1

Indeed, in this situation, it appears that the only valid purpose

\footnotetext{
${ }^{90}$ Jack B. Weinstein and Margaret A. Berger, 4 Weinstein's Evidence If 801(d)(1)(B)[01] (Matthew Bender, 1995), says that "as a practical matter, the jury in all probability would misunderstand or ignore a limiting instruction anyway, so there is no good reason for giving one."

I have two reactions to this statement. First, the problem does not reflect an inadequacy of jurors; the distinction I have drawn is paper thin, and I suspect that many judges as well would misunderstand and ignore it.

Second, as suggested below, limiting admissibility may be justified even assuming that a limiting instruction would not be effective.

${ }^{91}$ Note to Rule $801(\mathrm{~d})(1)(\mathrm{B})$.
} 
served by the distinction between rebuttal admissibility and substantive admissibility is a door-keeping one. That is, assuming that the statement is inadmissible before the charge of improper influence is inade, the making of the charge opens the door to rebuttal admissibility, and so too a path that leads to substantive admissibility. In this setting, Rule 801 (d)(1)(B) reflects a sound judgment that the rule against hearsay ought not place any restriction on the use of the statement.

Now suppose that, while the current testimony is of GENERAL ACCUSATION, the prior statement asserted GENERAL ACCUSATION AND DETAIL. In this setting, which resembles the one in Tome, there is what I will refer to as an overhang-the prior stateinent includes the proposition at issue but is more informative than the current testimony. The overhang changes the situation fundamentally in four respects. ${ }^{92}$

First, assuming the prior statement is admissible for both rebuttal and substantive purposes with respect to GENERAL ACCUSATION, there is a clear epistenological distinction between these uses of the statement and use with respect to DETAIL. The instruction, "You inay consider the prior statement as tending to prove GENERAL ACCUSATION, but do not consider it with respect to DETAII" is simple and quite clear; there is even the chance that the jury would obey it. It may be that the witness's assertion of DETAIL has solne value in rebutting the contention of improper influence with respect to GENERAL ACCUSATION, but even if so the distinction reinains clear: "You may consider the witness's prior assertion of DETAIL so far as it tends to prove that she would have testified to GENERAL ACCUSATION even had it not been for the intervention of the improper influence, but do not consider the statement as tending to prove that DETAIL is true."

Second, there is now a substantial consideration weighing in favor of exclusion with respect to DETAIL, even assuming the statement is admitted to prove GENERAL ACCUSATION; as discussed in Part $\Pi$, the fact that the witness has not testified to DETAI ineans that the party opponent inay be severely hindered in his ability to cross-examine her.

\footnotetext{
${ }^{92}$ See generally State $v$ Collins, 1989 Ohio App LEXIS 452 (holding that because the prior statement contained "an addition" to the current testimony it could not be considered a "consistent" statement within the Ohio rule, which is identical to the federal rule).
} 
Third, more is at stake than the manner in which the jury uses the prior statement to prove a given proposition, and the court is in a position to protect those stakes without having to rely on an abstruse instruction. For example, it may be that DETAIL closely bears on an element of a crime and that, absent admissibility of the prior statement of DETAIL, there would be insufficient evidence of that element to go to the jury. (With respect to GENERAL ACCUSATION, by contrast, there is already the witness's testimony asserting GENERAL ACCUSATION.) Tome illustrates this situation. With respect to two of the acts cliarged and found by the jury, there would have been no substantial evidence had it not been for the prior statements. ${ }^{93}$ As a consequence, a holding that the prior statement is inadmissible to prove DETAIL can be enforced by withholding that issue from the jury. The question whether the jury would adhere to an imstruction drawing barely comprehensible distinctions is thus rendered moot.

Even if the prior statement of DETAIL would support the proof of material issues, but is not essential to sustain a jury verdict with respect to any of them, effective tools are at hand to ensure that the jury does not use the statement to prove DETAIL. Sometimes the nature of the statement allows severance, so that the proponent is allowed to prove that the witness asserted GENERAL ACCUSATION but not that sle asserted DETAIL. And even where severance is not possible, another form of redaction might be appropriate, limiting and shaping what testimony may be given about the prior statement; in some cases, for example, the proponent's rebuttal needs might be satisfied by testimony that on a given date the witness made a statement indicating that she then believed GENERAL ACCUSATION to be true. ${ }^{94}$ Furthermore, outright

${ }^{93}$ A.T. did not testify to contact between Tome's mouth and her vulva, or between Tome's fingers and her genitalia; the evidence supporting these findings was supplied by the prior statements reported by Ecklebarger and Kuper, respectively. See above notes 20, 23 , and accompanying text; $T 725$ (prosecutor, in closing argument, referring to these statements as supporting findings of mouth-vulva and finger-genital contact). These statements were not necessary for the case as a whole to go to the jury, but the indictment specified four separate types of illicit acts, special interrogatories presented to the jury asked about the four, and the jury answered all four in the affirmative; it may be that Tome's sentence would have been lighter absent a jury finding of mouth-vulva and finger-genital contact. See generally 18 USC $\$ 2246(2)$, formerly $\$ 2245(2)$, listing the four types of conduct charged, among others, in the definition of "sexual act."

9t Analogously, in rape cases most states allow the prosecution to present evidence, even before the complainant has been impeached, that she made a "fresh complaint"-that is, one soon after the incident-because the absence of such a complaint might appear suspi- 
exclusion is also an available option: In some circumstances, the statement might have less value in supporting the witness's testimony of GENERAL ACCUSATION than prejudicial potential in tending to prove DETAL through means made unsatisfactory by the hindrance on cross-examination.

Fimally, the overhang deprives the door-opening argument of much of its force. At least where the proponent's rebuttal needs can indeed be protected by a severed statement or limited testimony about the statement, the fact that the party opponent suggested that testimony of GENERAL ACCUSATION was a product of improper imfluence should not give the proponent the ability to introduce a statement, not otherwise admissible, of DETAIL.

This analysis suggests a note of caution. In some cases, the court should ensure-by outright exclusion, severance of the statement, limitation of the testimony, or mstruction-that the jury does not use the prior statement to prove propositions to which the witness has not testified. Nothing in Rule $801(\mathrm{~d})(1)(B)$ precludes a ruling of himited admissibility in which the prior statement may be used only to prove (through both rebuttal and substantive use) the propositions asserted in the witness's current testimony. The Advisory Committee Note suggests that the drafters paid no attention to the overhang problem; they appear to have focused on the situation in which the witness reaffirms at trial the complete substance of the prior statement. There is no reason to suppose that they would be startled by an interpretation under which, if this condition does not hold, the Rule would apply only to the part of the prior statement that the witness does reaffirm. ${ }^{95}$

cious, but many jurisdictions limit the testimony that may be given on this basis to "a simple yes or no" in answer to the question "whether she made complaint that such an outrage had been perpetrated upon her." Woods $v$ State, 233 Ind 320, 326, 119 NE2d 558, 562 (1954).

Where the statement is not practically severable, a court might present the opponent with a choice. For example, suppose the witness testifies at trial to a general propositionsuch as "He was angry"- - and the prior statement offered to rehabilitate her does not quite assert that proposition but instead asserts details from which the more general proposition might be inferred-“" $\mathrm{He}$ was red and shaking." The court might rule: "I'm either going to admit Witness 2's testimony that Witness 1 said the accused was red and shaking, or if you prefer I'll allow Witness 2 to testify [or stronger yet: admit a stipulation] that Witness 1 made a statement indicating that she then believed the accused was angry. Choose your poison."

${ }^{95}$ Just the previous term, in Williantson $v$ United States, 114 S Ct 2431 (1994), the Court itself demanded fine sliaving of a statement for purposes of applying a hearsay exemption. Williamson held that the hearsay exception for declarations against interest, Rule 804(b)(3), incorporates a narrow meaning of "statement," as "a single declaration or remark," so that 
In Tome, however, the Justices seem not to have questioned that if the statement was validly offered to rebut a charge of "recent fabrication or improper influence or motive" it would be admissible in its entirety. ${ }^{96}$ The Court gave no suggestion that it would be troubled by the use of A.T.'s prior statements to sweep in a great deal of substance to which she did not testify. But, of course, the Court's holding was that Rule $801(\mathrm{~d})(1)(\mathrm{B})$ does not reinove the hearsay objection to her statements. It is conceivable that the Court was inotivated by the overhang problem, but responded obliquely by constructing an absolute premotive requirement. I will turn now to the merits of that requirement.

\section{The Premotive Requirement}

If a witness made a pretrial statement of ACCUSATION before an alleged improper influence arose, then ordinarily that statement will tend strongly-though not absolutely ${ }^{97}$ - to prove that the witness's trial testimony of ACCUSATION was not a product of that influence. If, by contrast, the witness inade the prior statement after the influence arose, it usually will have little or no probative value with respect to that question. Thus, many pre-Rules authorities indicated that a statement could rehabilitate a witness against a cliarge of improper inotive only if the statement was made before the motive arose.

In some circumstances, however, there is reason to believe that, even though the prior statement was made after the improper influence allegedly arose, that influence had less impact on the witness when she made the prior statement than it did at trial. In such circumstances, as Justice Breyer argued in his Tome dissent, the prior statement miglit have significant probative value, notwithstanding its timing, to rebut the charge of improper influence.

One example is a grudge, or other improper influence, that builds over time. ${ }^{98}$ If in its earlier, weaker form the influence did

the Rule "does not allow admission of nonself-inculpatory statements, even if they are made within broader narrative that is generally self-inculpatory." Id at 2431. Time will tell to what extent, if any, Williamsson requires distinction among "We [understood to be Sam and the declarant] robbed a bank on Friday morning," "Sam and I robbed a bank on Friday morning," and "I robbed a bank on Friday morning. Sam helped."

${ }^{96}$ The Brief for the Petitioner did not challenge the point.

${ }^{97}$ See note 89 (explaining why the inference is not absolute).

${ }^{98}$ See Tome, $115 \mathrm{~S} \mathrm{Ct}$ at 708 (Breyer, J, dissenting). 
not seem as likely as later to cause the witness to fabricate a story, then it might have significant probative value in rebutting the charge of improper influence. ${ }^{99}$

Second, although the influence may have reached full strength by the time of the prior statement, the circumstances or manner in which the witness made the statement might suggest that the influence had little impact on her. Justice Breyer inentioned the possibility that "the postmotive statement was made spontaneously." 100 As the Court of Appeals suggested, this might have been the case in Tome, though this conclusion depends on a view of child psychology-on an assessment of the child's inability to concoct a plan of false statement or to recognize how it might advance her interests-that is not self-evidently true. ${ }^{101}$

Third, even assuming that the witness fully understood how a statement of ACCUSATION might advance her interests, it may have appeared unlikely to her that this would occur in the particular setting in which she made the statement. Suppose, for example, that the witness declared ACCUSATION to an intimate of hers, someone whose hearing a truthful statement of ACCUSATION would not hurt her and whose hearing a false statement of ACCUSATION would not help her. If the accused later contends that the witness's trial testimony of ACCUSATION is a product of a grudge, this prior statement should have rehabilitative value-even if it was made after the grudge arose. ${ }^{102}$

99 The absolute premotive rule adopted by Tome can accommodate this situation, though not in an entirely satisfactory inanner. The influence could be deemed not to have arisen for purposes of the premotive rule until such tine as it appeared to achieve soine level of strength, presumably enough to make it likely that given the influence the wituess would declare ACCUSATION even without beheving it. Put another way, the strength of the influence could be treated as a binary, rather than continuous, function.

${ }^{100} 115 \mathrm{~S} \mathrm{Ct}$ at 708. Rule 803(2) would remove the hearsay bar to some, but not all, such statements. To satisfy that Rule, the statement must "relat[e] to a startling event or condition" and be "made while the declarant was under the stress of excitement caused by the event or condition."

${ }^{101}$ See note 38 (Court of Appeals doubting ability of A.T. to make statements as "the result of a ealculated scheme to deceive").

102 Thus, on some matters, an observer might have an incentive to lie to her boss or to a court but not to her husband.

Again, a court eager to admit this statement under Rule 801(d)(1)(B), and yet purport to adhere to an absolute premotive rule, might conclude that, although the grudge had arisen, the particular motive to he-to accomphish harm to the party opponent by making a statement that would have operative force in litigation-had not. But, of course, this manipulation would weaken the premotive requirement. 
Sometimes, then, when a witness testifies to a given proposition and the party opponent charges that she did so because of an improper influence, a prior statement by the witness of that proposition might help rebut the charge even though the statement was made after the influence arose. That does not indicate that all postmotive statements, or even all those with such rebuttal value, should be admitted-but it does cut sharply against an absolute exclusion of those statements from the exemption granted by Rule $801(\mathrm{~d})(1)(\mathrm{B})$.

In Tome, the Court belittled the significance of the probative value of such statements in determining admissibility. Hearsay, it pointed out, is often relevant, but is nevertheless presumptively inadmissible. ${ }^{103}$ The argument was a strange one for the Court to make, given that earlier in the opinion it had expressed doubts about whether the policies underlying the hearsay rule apply to the prior consistent statements of a witness at all ${ }^{104}$ _ and it made no attempt to argue that they do. Indeed, it could hardly do so without questioning the position it had taken in the Green-NelsonOwens line that cross-examination is not hindered by the fact that a prior statement of the witness, rather than her current testimony, is at stake.

What other arguments support an absolute premotive requirement? The history of the Rule is not conclusive, though pre-Rules courts and commentators did frequently declare that only premotive statements could be admitted for rebuttal purposes. As pointed out by Justice Breyer, this view was not quite unamimous. ${ }^{105}$ Perhaps more significantly, it appears that the premotive rule was perceived as simply a matter of relevance: A statement made after the motive arose could not be admitted to rehabilitate, because it had no rehabilitative value. Thus, $M c$ Cormick on Evidence, in a passage most of which the Court quoted in Tome, declared that

if the attacker has charged bias, interest, corrupt influence, contrivance to falsify, or want of capacity to observe or remember, the applicable principle is that the prior consistent state-

\footnotetext{
${ }^{103} 115 \mathrm{~S}$ Ct at 704.

${ }^{104}$ Id at 701.

${ }^{105}$ See id at 708 (Breyer, J, dissenting).
} 
ment bas no relevancy to refute the charge unless the consistent statement was made before the source of the bias, interest, influence or incapacity originated. ${ }^{106}$

Ordinarily, this argument is sound, but it does not apply where unusual circumstances, such as those described above, do give a postmotive statement significant rehabilitative value. The preRules courts and commentators appear never to have squarely addressed the proposition that a postmotive statement could never be admitted for rehabilitative purposes notwithstanding such circumstances. ${ }^{107}$ Neither, for that matter, have post-Rules decisions of the lower courts adopting a premotive requirement. ${ }^{108}$

Of course, arguably the Federal Rules, though extending the rule on prior consistent statements to substantive as well as rehabilitative admissibility, took the prevailing rule as it was usually articulated, and so incorporated the premotive requirement. Such a reading of history, however, gives an unfortunate freezing effect to the Rules. Before the Rules, I have suggested, a court attentive to the policies underlying evidentiary rules and not merely to casual statements of them should have been willing to consider whether a particular statement had rehabilitative value even though it was made after the improper motive arose. A post-Rules court should not be precluded from such consideration unless the intent of the drafters, or the language of the Rule itself, is very clear.

The drafters' commentary to Rule $801(\mathrm{~d})(1)$ (B) is brief, clumsy,

${ }^{106}$ Edward Cleary, gen ed, McCormick on Evidence $\$ 49$, at 105 (West, 2d ed 1972) (emphasis added). This passage was essentially identical im the first edition, by Charles T. McCormick, $\$ 49$, p 108 (1954). See also John Henry Wigmore, 4 Evidence $\$ 1128$ at 268 (Little, Brown, 4th ed, James H. Chadbourn, rev, 1972), quoted in Tome, $115 \mathrm{~S} \mathrm{Ct}$ at 700 ("A consistent statement, at a time prior to the fact said to indicate bias . . . will effectively explam away the existence of a force of the impeaching evidence" (emphasis in original)).

${ }^{107}$ At least those cited by the Court in Tome did not, nor have I found any that did.

${ }^{103}$ Some of these decisions have been very conclusory, with little or no discussion; see, for example, United States $v$ Henderson, 717 F2d 135, 138 (4th Cir 1983). Others have been based on the propositions recited above, that a postmotive statement "is not relevant to the rebuttal of a charge of recent fabrication" because "mere repetition does not imply veracity." See, for example, United States v Bowman, 798 F2d 333, 338 (8th Cir 1986) (characterizmg this as the reasoning of courts adopting premotive rule, and joining them); see also note 106 (McCormick, Wigmore). As with respect to the older cases, this reasoningnot so much a statement of an evidentiary rule as an exercise of logic about the most common type of postmotive statenent-does not address the occasional circumstance in which a postmotive statement does have rehabilitative value. 
and uninformative. ${ }^{109}$ As for the text of the Rule, it certainly includes no explicit statement of a premotive requirement-such as "to rebut an express or implied charge against the declarant of fabrication or improper influence or motive that arose after the statement was made." I do not believe the presence of the word "recent" before "fabrication" in the Rule can be taken to mandate such a requirement. Let us put aside the argument made by the Government in Tome that "recent" is meant only to modify "fabrication." Though the argument is not utterly implausible, ${ }^{110}$ neither is it persuasive, ${ }^{111}$ and Justice Breyer's formulation-that the statement must show "that the witness did not recently fabricate his testimony as a result of an improper influence or motive" seems useful. Even on this reading, however, "recent" is notoriously ambiguous. If taken literally, it seems to address the temporal relation of the fabrication, influence, or motive to the trial, not to the statement. Moreover, it seems clear that the word cannot be taken literally, in the dictionary sense of "occurring at a time immediately before the present." 113 Thus, "recent" should be given a construction that fits the rehabilitation idea underlying the Rule.

\footnotetext{
${ }^{109}$ See note 82.

${ }^{110}$ Note that, as the Government in effect argued, Brief for the United States at 23-24, "[recent fabrication] or [improper influence or motive]" reads more smoothly than "[recent] [fabrication or improper influence or motive]." Indeed, pre-Rules sources suggest that "recent" was attached to "fabrication" and not to "influence or motive." See M. C. Dransfield, Annotation, Admissibility, for purpose of supporting impeached witness, of prior statements by bim consistent with bis testimony, 75 ALR2d 909, 944 ("an examination of the later cases shows that the time of making the consistent statements that are sought to be used to support the credibility of the witness who has been impeached on the ground of having a motive to falsify, or having recently fabricated his testimony, has played an important part in their admissibility for such purposes").

"II See Brief for Petitioner at $17 \mathrm{n}$ 12. The "fabrication" seems to be a product of, rather than on the same plane with, the "improper influence or motive."

$112115 \mathrm{~S} \mathrm{Ct}$ at 707 . See also Annotation, cited in note 110, 75 ALR2d at 944 ("a fabrication of recent date").

${ }^{113}$ American Heritage Dictionary 1508 (Houghton, Mifflin, 3d ed 1992). See, for example, People $v$ Singer, $300 \mathrm{NY} 120,124,89 \mathrm{NE} 2 \mathrm{~d} 710,711$ (1949) (rejecting an interpretation of "recent" as meaning "that the witness' statements at the trial must have been assailed as having been fabricated at some point just before the trial," and adopting "a relative, not an absolute meaning," under which the opponent "is charging the witness not with mistake or confusion, but with making up a false story well after the event. 'Recently fabricated' means the same thing as fabricated to meet the exigencies of the case." (citations omitted)); Judith A. Archer, Note, Prior Consistent Statements: Temporal Admissibility Standard Under Federal Rule of Evidence 801(d)(1)(B), 55 Ford L Rev 759, 768-69 (1987) ("The term 'recent' as used by FRE 801(d)(1)(B) indicates that the testimony was contrived at some point after the impeaching event, rather than proximate to its being given at trial.").
} 
In my view, "arising recently enough that the prior statement retains substantial rebuttal value" satisfies this standard and does not distort the language. In most cases-but not in all-this construction would be equivalent to "arising after the statement was made."

\section{Reconstructing Rule 801(d)(1)(B)}

The arguments I have presented so far in this article suggest that-assuming the prevailing structure of bearsay law-Rule $801(d)(1)(B)$ and its state counterparts should take on this shape: First, the court should assess the rebuttal value of the prior statement. Rebuttal value requires both need to rebut the charge and effectiveness in doing so. Ordinarily, but not inevitably, a statement inade after the alleged improper influence arose will not be effective in rebutting the charge that the witness's trial testimony is the product of the influence. Second, if the prior statement appears to have substantial rebuttal value, the court should consider factors weighing against admissibility of the statement. These include expenditure of time and, if the prior statement includes an overhang of assertions not included in the witness's trial testimony, the prejudice that this potentially creates, especially in hindering the party opponent's ability to cross-examine the witness with respect to those statements. If the negative factors are substantial, the court should consider excluding the statement, redacting the statement, or otherwise limiting the information that may be presented about it or the use that the jury may make of it.

How would this system work in Tome? If, as both the Court of Appeals ${ }^{114}$ and the Supreme Court ${ }^{115}$ believed, the charge of improper influence was a weak one, the need for rebuttal was correspondingly weak. The spontaneity of A.T.'s first stateinent, to her babysitter Rocha, might give that statement some rebuttal value, notwithstanding that the statement was made after the alleged influence arose. The subsequent pretrial statements, made after interrogation of A.T. began, have far less rebuttal value, and their

$1143 \mathrm{~F} 3 \mathrm{~d}$ at 351 ; see note 38.

"115 $115 \mathrm{~S} \mathrm{Ct}$ at 705 ("a rather weak charge that A.T.'s testimony was a fabrication created so the child could remain with her mother"). 
incremental value would be less still if the first statement were admitted. Moreover, it was principally the subsequent statements that added information not contained in A.T.'s trial testimony. Though the first statement- "my father gets drunk and he thinks I'm his wife"-added some substance to the current testimony, this could easily be suppressed from Rocha's testimony. ${ }^{116}$ Thus, the trial court could have decided to admit the first statement, in some form, but not the others. I do not mean to suggest that this outcome would be indubitably correct, only that it would be plausible, within the trial court's discretion.

But in Tome the Court perceived discretion itself as part of the problem. The Court cited the Advisory Committee's concern that making admissibility of hearsay depend entirely on a case-by-case evaluation of probative value would make it too discretionary and so too unpredictable. ${ }^{17}$ The Committee's concern was valid, in my view, principally because the Court has not been able to enunciate a robust conception of the Confrontation Clause independent of ordinary hearsay law. Even accepting that validity, however, it seems for several reasons to have little bearing on this case.

First, the Committee's expressed concern was at a global level, invoked in opposition to the idea that the prevailing structure of doctrine, a presumptive exclusion of hearsay qualified by numerous exemptions, should be replaced by a system generally dependent on a balance of probative value and prejudicial potential. ${ }^{118}$ But recognizing the dangers of such a wide-open system does not preclude allowing the trial courts a little bit of leeway so that they

\footnotetext{
${ }^{116}$ Moreover, in one respect the statement might significantly help Tome: A.T.'s statement that her father "thinks I'm his wife" suggests a level of sexual awareness that one might not expect in a girl of her age, making it far more plausihle than otherwise might be supposed that she fabricated a story of sexual abuse.
}

$117115 \mathrm{~S} \mathrm{Ct}$ at 704.

118

Abandonment of the system of class exceptions in favor of individual treatment in the setting of the particular case, accompanied by procedural safeguards, has been impressively advocated. . . . The Advisory Committee has rejected this approach to hearsay as involving too great a measure of judicial discretion, minimizing the predictability of rulings, enhancing the difficulties of preparation for trial, adding a further element to the already overcomplicated congeries of pretrial procedures, and requiring substantially different rules for civil and criminal cases.

Advisory Committee's Introductory Note to Article VIII, quoted in part in Tome, $115 \mathrm{~S}$ $\mathrm{Ct}$ at 704 . 
can implement sensibly the narrow exemption provided by Rule 801(d)(1)(B). To quote Justice Cardozo, albeit far out of context, "Discretion [given the construction I suggest] is not unconfined and vagrant. It is canalized im banks that keep it from overflowing."119

Second, even with a premotive requirement attached, Rule $801(d)(1)(B)$ is dependent on an exercise of discretion. Recall that the predicate for application of the Rule, which allows use of the prior statement for a hearsay purpose, is that the statement is admissible for a rehabilitative purpose. But determining admissibility for that nonhearsay purpose is a discretionary matter. Tome characterized as "rather weak" the cliarge that A.T. had fabricated her testimony so that she could live with her mother, and it complained that "the Government was permitted to present a parade of sympathetic and credible witnesses who did no more than recount A.T.'s detailed out-of-court statements to them." 120 Now suppose A.T. had made all those statements at a time when, so far as she knew, a change of custody arrangements was not in the offing. Satisfaction of the preinotive requirement might mean that the earlier statements more clearly rebut the fabrication chargebut that charge would be just as weak as in the actual case, meaning that the parade of witnesses would be, if anything, even less necessary and appropriate. Presumably the Court would not object to the trial court's exercise of discretion to admit ouly one prior statement in rebuttal. Allowing the trial court to discern rebuttal value even in soine postmotive statements would prevent some cases from being decided by a shortcut rule, but it would not introduce discretion to a realm where it had been foreign.

Third, one aspect of discretion under the construction I suggest is concerned not with the premotive requireinent but with the overhang problem-the danger that Rule $801(\mathrm{~d})(1)(\mathrm{B})$ will automatically sweep into evidence prior accusatory statements that the witness did not assert in her trial testimony and as to which the accused has not had an adequate opportunity to cross-examine. If, within the present framework of hearsay law, the only way of preventing this is by an exercise of discretion, so be it.

"19 Panana Refining Co v Ryan, 293 US 388, 440 (1935) (dissenting opinion).

${ }^{120} 115 \mathrm{~S} \mathrm{Ct}$ at 705. 
Fourth, we can anticipate that trial courts' attempts to reach sensible results will continue to find an outlet; if Tome's absolute premotive requirement precludes a candid exercise of discretion in applying the Rule, trial courts will tend to mampulate the scope of the requirement. ${ }^{121}$ In some cases, it may be that the principal effect of Tome will not be to limit what trial courts do, but to prevent them from being frank in doing it.

Finally, Tome itself makes explicit that, if a statement fails the premotive requirement, it may nevertheless avoid the rule agaimst hearsay by the most discretionary route of all, the residual exception provided in Rule 803(24); indeed, the Court expressly invited the Court of Appeals to consider whether A.T.'s prior statements should be admitted pursuant to that Rule. ${ }^{122}$ Rule 803(24) and its virtually identical counterpart for unavailable declarants, Rule 804(b)(5), offer trial courts notoriously wide-open and virtually uncontrollable discretion to admit hearsay that does not fall within any categorical exception. ${ }^{123}$ When all is said and done, the admissibility of a prior statement like those of A.T. will often depend in large part on whether the trial court believes it to be truthful. ${ }^{124}$ Tome's efforts to maintain bright-line rules in the hearsay realm may look increasingly unrealistic as trial courts continue to indulge themselves in the luxurious discretion provided by the residual exceptions.

\footnotetext{
${ }^{121}$ See notes 99, 102.
}

$122115 \mathrm{~S} \mathrm{Ct}$ at 705.

${ }^{123}$ See, for example, 3 Stephen A. Saltzburg, Michael M. Martin, and Daniel J. Capra, Federal Rules of Evidence Manual 1447-48 (6th ed 1994); Myrna S. Raeder, The Hearsay Rule at Work: Has It Been Abolished De Facto by 7udicial Discretion, 76 Minn L Rev 507 (1992).

${ }^{124}$ The trial judge held that A.T.'s August 22 statement to Rocha was admissible alternatively under Rule 803(24), but not her August 27 statements. He emphasized that the earlier statement was spontaneous, that it was made to ask an adult for help, and that it related to her current emotional state (though of course it narrated past facts). T 210-11.

On remand after the Supreme Court's decision, the Court of Appeals for the Tenth Circuit has decided that the statements made to Ecklebarger and Rocha did not satisfy the residual exception, principally because they were made too long after the events they described. United States v Tome, 61 F3d 1446, 1451-54 (10th Cir 1995); apparently the Government did not argue for the admissibility of the statements to Padilla. Id at 1454-55. The Court of Appeals held, however, that the statements to the three pediatricians were admissible under Rule 803(4), as having been made for purposes of medical treatment or diaguosis-even though A.T. presumably had no idea of the therapeutic or diagnostic value of some of the information she provided, especially that identifying her assailant. Id at 1449-51. This latter issue, which drew a sharp dissent from Judge Holloway, could plausibly bring the case back to the Supreme Court if Tome is found guilty on the retrial. 


\section{Conclusion and Reflection}

Tome deepens the ever-expanding thicket of hearsay law. ${ }^{125}$ In my view, the question that the Court actually decided was a trivial one, and it gave an unduly rigid answer. The Court need not have granted certiorari, for there was no blazing conflict among the circuits. Courts rejecting a premotive requireinent recognized that most often postmotive statements lack significant rehabilitative value. And courts articulating the requirement did not confront the issue of whether it really is an absolute one, to be imposed even on the unusual postmotive statement that does have such value, rather than inerely a statement of the logic to be apphed in the usual case. In adopting an absolutist rule, the Court was supposedly unotivated by fear of judicial discretion-but it put its reliance on the most wide-open aspect of modern hearsay law, the residual exceptions. Moreover, the Court sowed potential confusion as to the nature of Rule 801 (d)(1)(B). The Court's language (inadvertently, I think) seems to treat the Rule as one setting out the exclusive circumstances in which a prior consistent statement inay be used to rehabilitate the testimony of a witness. Lower courts may infer from this that a statement that does not satisfy the Rule may not be used for rehabilitation.

Tome is frustrating because, while the issue actually decided by the Court was so narrow, the case itself highlights numerous broader issues that must be addressed if hearsay law is to be inproved. The Tome Court cannot be faulted for failing to resolve issues not actually presented to it, or to write a dissertation on the law of hearsay. But it is fair game, I think, for commentary to point to issues that, given an ideal hearsay system, might have played a larger role in resolving the admissibility of A.T.'s prior statements.

In Tome, the Court showed no genuine recognition that, when a witness's prior statement is admitted into evidence but the witness's testimony on direct or redirect does not confirm all the substance of the statement, the opponent's opportunity to crossexamine is severely limited. Indeed, given Green, Nelson, and Owens, the Court felt no need to discuss the issue. The Court

${ }^{225}$ See John M. Maguire, The Hearsay System: Around and Through the Thicket, 14 Vand L Rev 741 (1961). 
never even mentioned Tome's constitutional right of confrontation.

More broadly, the Court showed no awareness at all of what I have called the overhang situation, in which a prior statement offered to rehabilitate a witness's testimony contains significant information not contained in the testimony. Thus, the Court never addressed the possibility that a statement ineeting this description should be analyzed any differently from one that asserts only propositions to which the witness has testified.

I believe that recognition of these issues is necessary if prior statements are to be addressed sensibly within the prevailing doctrine of hearsay law. But Tome also presents some factors that inight be significant in an attempt to put the law of hearsay and confrontation into a fundainentally different framework.

First, Toine was a criminal defendant, and the prior statements offered against him accused him of a crime. The Court put no weight on these factors, which play no role in Rule 801(d)(1)(B). But it seeins to me that they make the adinissibility of hearsay suspect. In iny view, the right to confront witnesses under the Sixth Amendinent should not apply to all hearsay declarants. But if a declarant makes an accusatory statement, then ordinarily that statement should not be admitted into evidence unless the accused has had an opportunity to confront the declarant. A strong protection of the confrontation right not dependent on the mainpulable bounds of hearsay law ${ }^{126}$ would, I believe, inake it possible to take a far more hospitable attitude toward hearsay when the confrontation right is not at stake.

Second, A.T., the declarant, was a young child, both when she made the statements and when she testified at trial. Perhaps her understanding and cognitive abilities were so undeveloped when she made the statements that, like a barking dog or a inechanical instrument, she should not be considered a "witness" within the meaning of the Confrontation Clause. Moreover, there is some suggestion in the record that A.T.'s difficulty in testifying was attributable to fear of Tome and that his wrongful conduct created

\footnotetext{
${ }^{126}$ The Supreme Court has defined the confrontation right so as to make it nearly congruent with the provisions of the Federal Rules of Evidence on hearsay. See, for example, White v Illinois, 502 US 346 (1992).
} 
this fear. ${ }^{127}$ If it could be shown to a high degree of confidence that both these propositions were true, then perhaps Tome should be held to have forfeited the right to object to admissibility of the prior statements.

The presentation of these thoughts here is obviously very sketchy, for it would take a series of other articles to explore them in depth. But I believe that focusing on this type of issue (Was the opportunity for cross-examination satisfactory? Is this the type of declaration, and declarant, to which the confrontation right should apply? Has the accused forfeited his right to object?) will lead to a far inore satisfying style of analysis of hearsay issues than the mechanical approach reflected by Tome. If the law of hearsay is to be reshaped, as many besides me have contended it should be, ${ }^{128}$ a change in the Rules will certainly be necessary. But so too will be a change in the law of confrontation. And in that respect, reform depends on the Supreme Court. Most broadly, it can attempt to define the confrontation right without relying on the perplexing categorizations of hearsay law. More narrowly, it should recognize that the mere fact that the declarant of a prior statement testifies at trial does not necessarily imply that the party opponent has had an adequate opportunity to cross-examine.

${ }^{127} \mathrm{~T} 91$ (prosecutor saying A.T. is "very frightened" of Tome), 143 (A.T. saying she is afraid to go back to Tome), 162 (A.T. saying that she is afraid to live with him "[b]ecause he did something bad"), 681, 687 (guardian ad litem testifying that in 1991, after A.T. had been removed from Tome's custody, she was fearful of him and asked that visitation be stopped).

${ }^{128}$ See, for example, the articles and essays from the Minnesota Hearsay Reform Conference, 76 Minn L Rev 363-889 (1992). 